\title{
University accounting programmes and the development of Industry 4.0 soft skills
}

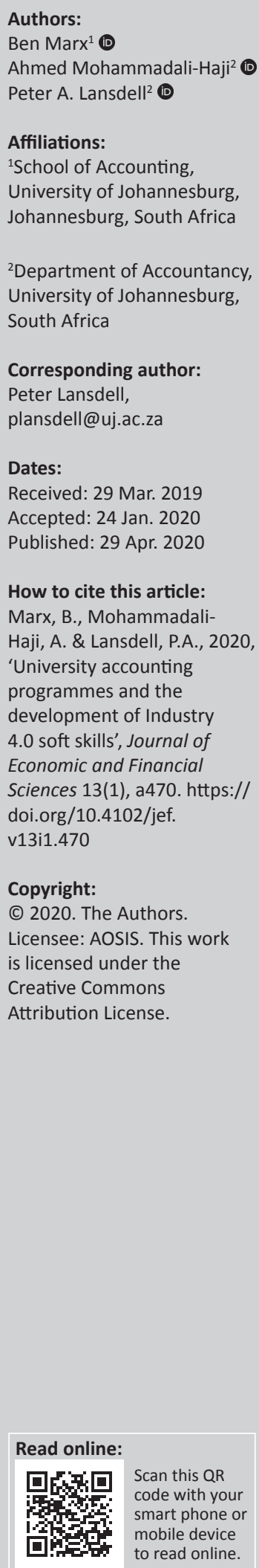

Orientation: The Fourth Industrial Revolution (Industry 4.0) is anticipated to have a significant impact on the future generation of professional accountants. Accordingly, current and aspirant accountants are expected to acquire and develop soft skills, which will enable them to add value as responsible business leaders and thrive within Industry 4.0.

Research purpose: The overarching purpose of this study was to elicit the perceptions of entry-level chartered accountants in South Africa (CAs [SA]) on the development of soft skills during a university accounting programme, specifically those soft skills demanded by Industry 4.0 .

Motivation for the study: Limited research appears to exist with specific focus on the perceptions of entry-level CAs(SA) regarding the development of soft skills during a university accounting programme.

Research approach/design and method: University accounting programmes accredited with the South African Institute of Chartered Accountants (SAICA) were the focus of the empirical work. A questionnaire was used to obtain the exploratory results, which yielded a response rate of $40.77 \%$.

Main findings: The quantitative results indicated that the particular accounting programme in question was perceived to have developed most of the soft skills required by Industry 4.0.

Practical/managerial implications: One of the implications of this study is that the university accounting programme providers should place more emphasis on the development of soft skills, specifically those related to Industry 4.0.

Contribution/value-add: The results of this research contribute to the existing body of knowledge by articulating the views of entry-level CAs(SA) on the development of Industry 4.0 soft skills.

Keywords: Industry 4.0; soft skills; entry-level accountants; accounting education; professional competence.

\section{Introduction}

The environment in which professional accountants work and function is subject to constant change. In the last decade, these changes were primarily attributed to advances in information technology and the globalisation of economies on a large scale (Tan \& Laswad 2018). More recently, these challenges have shifted focus to the Fourth Industrial Revolution (Industry 4.0) and its impact on the required skills set of the future generation professional accountants (Gray 2016). Consequently, there can be no doubt that Industry 4.0 will have a profound impact on the education of professional accountants (Burrows 2017; Gray 2016; Strauss 2016; UWN 2016; World Economic Forum 2016). Specifically, this impact will be reflected in a stronger focus on soft skills to ensure the relevance of the accountancy profession in the context of Industry 4.0 (Baldwin, Brown \& Trinkle 2006; Meads 2017; Rudman \& Sexton 2017; Schwab 2016; Van Oordt \& Sullivan 2017; World Economic Forum 2016).

\section{Orientation}

Over the last decade, extensive research has been conducted on the soft skills expected from accounting graduates (Chen 2013; Milliron 2012; Siriwardane, Low \& Blietz 2015; Tan \& Laswad 2018; Wells et al. 2009). Most of these studies have been conducted from the perspective of accounting programme providers (universities), future employers of accounting graduates or accountancy professional bodies. The majority appears to conclude that accounting education 
fail $[s]$ to meet the expectations of employers or [is] not concurrent with the requirements of the real world of business (Agyemang \& Unerman 1998; Birkett 1993; Brown \& McCartney 1995; Burrows 2017; Hassall et al. 2005; Hutchinson \& Fleischman 2003; Kim, Ghosh \& Meng 1993; Mohamed \& Lashine 2003; NCVER 2003; Usoff \& Feldmann 1998; UWN 2016). These studies also suggest that the accounting programme has the main responsibility to develop entry-level accountants' soft skills (Ashbaugh \& Johnstone 2000; Bonk \& Smith 1998; Boyce et al. 2001; Greenberg 1997; Henderson 2001; Howieson 2003, 2014; Institute of Chartered Accountants Australia [ICAA] 1998; Jackson \& Cherrington 2002; Johnstone \& Biggs 1998; Kern 2002; Sergenian \& Pant 1998; Tempone \& Martin 2003; Tinker \& Feknous 2001). As a result, concerns might once again emerge regarding current accounting programmes, and specifically their ability to ensure the professional development of entry-level accountants' soft skills in order to sufficiently address the demands of Industry 4.0.

Various authors often suggest that the accounting programme is seen as being primarily responsible for the development of soft skills (Ballantine \& McCourt Larres 2009; Barac \& Du Plessis 2014; Bui \& Porter 2010; Courtis \& Ziad 2002; UWN 2016). Moreover, as indicated in the competency frameworks of various accountancy professional bodies, accounting programmes must include the development of soft skills in their curriculum (South African Institute of Chartered Accountants [SAICA] 2014). In fact, by 2025 the World Economic Forum (WEF) predicts that entry-level accountants with well-developed soft skills will be a 'key ingredient' for the success of their future world of work, given the anticipated impact of Industry 4.0 on the accountancy profession as a whole (Olivier 2017; World Economic Forum 2016).Within this context, there exists a need to look beyond the perceptions of accounting programme providers (universities) (Craig 2015; International Accounting Education Standards Board [IAESB] 2014; Jackling \& De Lange 2009). Therefore, a transformative approach is required that expands on the thinking about the 'type' of soft skills to be developed by universities in order to meet the demands of Industry 4.0 (Barac \& Du Plessis 2014; Olivier 2017; Schwab 2016; Wunsche 2016).

\section{Objective and limitation}

Entry-level accountants are key stakeholders in accounting education, and they can offer a unique perspective in identifying the soft skills that an accounting programme has developed (Barac 2009; Steenkamp 2012; Watty, Jackling \& Wilson 2012). Hence, their perceptions would make a valuable contribution to the debate as to whether a university accounting programme is developing the relevant soft skills. Accordingly, the overarching objective of our study is to inform stakeholders in accounting education about 'how' accounting graduates perceive the development of Industry 4.0 soft skills during a university accounting programme.
To explore the perceptions of South African entry-level chartered accountants (CAs[SA]) regarding the development of soft skills, we formulated the following research questions:

- Are entry-level CAs(SA) aware of the required soft skills in terms of Industry 4.0 ?

- What are the perceptions of entry-level CAs(SA) about the role which a university accounting programme plays in developing Industry 4.0 soft skills?

- Is the university accounting programme perceived by entry-level CAs(SA) to develop the soft skills required by Industry 4.0 ?

- To what extent do entry-level CAs(SA) perceive a university accounting programme to have developed the soft skills demanded by Industry 4.0?

One of the limitations of the study is its focus on the South African Institute of Chartered Accountants (SAICA)-accredited university accounting programme providers and accounting graduates aspiring to become CAs(SA) (see the 'Study framework' section). Consequently, the findings may not be representative of the views of nonSAICA-accredited programme providers or graduates not entering the CA(SA) profession, for example, the South African Institute of Professional Accountants (SAIPA). However, because of the global standing of the SAICA, the findings could be of interest to non-SAICA-accredited accounting programmes in South Africa.

\section{Contribution}

This study contributes to the extant knowledge on entry-level accountants' soft skills (specifically those related to Industry 4.0) by exploring their views on the development of these skills during an accounting programme. Heeding the suggestion that graduates' perceptions play an important role (Barac 2009; Paisey \& Paisey 2004; Steenkamp 2012), we used a novel approach to explore the research questions. Unlike most prior studies related to soft skills development, which are mainly focused on the perceptions of academics, employers or professional bodies (Tan \& Laswad 2018), we used a questionnaire to determine the perceptions of entry-level $\mathrm{CAs}(\mathrm{SA})$ regarding the extent to which soft skills were developed during an accounting programme. Hence, applying the suggestion by Kennan et al. (2009), obtaining the views of the CAs(SA)s, as the recipients of the soft skills, could provide a clearer understanding of the extent to which these skills were perceived to be developed within the accounting programme. These 'grassroots' perspectives make a valuable contribution to the debate on whether or not current accounting programmes are effective and, indeed, whether they are the 'perfect home' for teaching soft skills.

The contribution of our study is therefore threefold: it provides useful insights into (1) the value that entry-level CAs(SA) accord to the development of soft skills within a university environment, (2) the extent to which they perceive the soft skills to be developed and (3) supporting academics who believe that certain soft skills are better developed 
outside the accounting programme, for example, during an SAICA-accredited training programme of 3 years prior to entering the $\mathrm{CA}(\mathrm{SA})$ profession. The findings should also be of interest to accounting professional bodies and the academic community at large, as a university accounting programme has a social responsibility to meet the demands of employers of future accountants (Tan \& Laswad 2018).

The article is organised as follows. The next section reviews the literature dealing with the impact of Industry 4.0 on entry-level accountants' soft skills development and where such skills could be best developed. This is followed by a discussion of the framework used. The research method and findings are then presented. The final section concludes with implications for educating future generation CAs(SA), with specific focus on well-developed soft skills.

\section{Literature review}

The literature review covers three broad topics: (1) the demands of Industry 4.0, (2) the impact of developing entry-level accountants' soft skills and (3) the importance of developing such skills by a university accounting programme.

\section{Industry 4.0 and its impact on the education of entry-level accountants}

The late 18th century marked the first industrial revolution, with steam power revolutionising the industry (Davis 2016). A second revolution occurred during the 19th century, when electricity and assembly lines led to mass production. This was followed by the third industrial revolution in the 1960s, with advances in computing (Davis 2016). Currently, a another revolution is taking place. Known as the Fourth Industrial Revolution (Industry 4.0), it is seen as the 'next evolution of automating processes, making them smarter and better' (Schwab 2016). Originating in Germany, Industry 4.0 is a strategic initiative to provide advanced manufacturing solutions (Schwab 2016), which could have a beneficial impact on companies' profits globally.

The WEF defines Industry 4.0 as 'the possibilities of billions of people connected by mobile devices, with unprecedented processing power, storage capacity and access to knowledge as unlimited' (Schwab 2016). The accountancy profession is undoubtedly linked to the challenges that Industry 4.0 brings, as it is anticipated that a significant portion of the roles and responsibilities of future generation accountants will be automated (Schwab 2016). Accordingly, the accountancy profession must 'reinvent itself, in order to remain relevant' (Olivier 2017). The role of the accounting programme is therefore emphasised in equipping students with the necessary skills to adapt to Industry 4.0, which is directly relevant to this study.

Undoubtedly Industry 4.0 will have a profound impact on the world, business and how humans conduct their daily jobs - it will be 'the future world of work' (Schwab 2016). Consequently, the knowledge, qualities and skills of newly qualified accountants are also likely to change. In fact, the WEF's Future of Jobs report suggests that approximately 35\% of core skills of the accountancy profession is likely to change between 2015 and 2020 in order to meet the demands of Industry 4.0, thereby ensuring the relevance of the profession globally (World Economic Forum 2016). The impact of Industry 4.0 will therefore need to be considered in such a way that the future generation of professional accountants is educated in order to maintain the relevance of the profession in the years to come (Craig 2015).

Globally, accountancy professional bodies are well aware of the need to change in order to remain relevant and, as the institutions responsible for developing accountants' professional competence, it has begun to ask critical questions to address the anticipated changes of Industry 4.0. For example, in South Africa, the SAICA has asked the following questions: (1) what competencies should aspirant CAs(SA) be equipped with to ensure that they remain relevant once they enter the profession and workplace?, (2) how should existing CAs(SA) change their skills mix in order to remain relevant?, (3) what impact will changing technology have on the future role of CAs(SA)? and (4) what will happen to the accounting profession if the necessary steps are not taken to remain relevant?

It is still uncertain, however, as to exactly what skills set aspirant $\mathrm{CAs}(\mathrm{SA})$ will need to acquire to ensure their future relevance. The SAICA's CA 2025 project is therefore investigating what these qualities, skills and competencies are likely to be (Olivier 2017). Once finalised, the SAICA competency framework will be amended, but it is likely to be reflected in greater importance accorded to the development of appropriate soft skills prior to entering the CA(SA) profession (Olivier 2017).

\section{Changes in the required skills set of future generation accountants}

Over the last decade, many researchers have argued that the traditional role of a professional accountant as a 'score keeper' is no longer relevant (Picard, Durocher \& Gendron 2014:197). Instead, professional accountants should add value to business entities as responsible business leaders (SAICA 2014). In the past, some professional accountants attributed their job success, in the broad field of accountancy, solely to their technical accountancy knowledge obtained during an accounting programme (Rebele 1985). However, research has challenged the notion that technical accountancy knowledge ranks above soft skills (Agyemang \& Unerman 1998; Birkett 1993; Brown \& McCartney 1995; Hassall et al. 2005; Hutchinson \& Fleischman 2003; Kim et al. 1993; LaFrancois 1992; Mathews, Jackson \& Brown 1990; Mohamed \& Lashine 2003; NCVER 2003; Usoff \& Feldmann 1998). Instead, many employers now simply presume entry-level accountants' technical accountancy knowledge (Bui \& Porter 2010; Burrows 2017; UWN 2016). Instead, soft skills are now considered to contribute to their career success as well as meeting the expectations and requirements of newly qualified 
professionals (Agyemang \& Unerman 1998; Birkett 1993; Brown \& McCartney 1995; Burrows 2017; Hassall et al. 2005; Hutchinson \& Fleischman 2003; Kim et al. 1993; LaFrancois 1992; Mathews et al. 1990; Mohamed \& Lashine 2003; NCVER 2003; Usoff \& Feldmann 1998; UWN 2016).

The changes being brought on by Industry 4.0 could once again create tension between employers and education providers as the job market is likely to continue to expect accounting programme providers to equip accounting graduates with the requisite soft skills. This is particularly relevant within the context of the soft skills demanded by Industry 4.0.

The International Federation of Accountants (IFAC) affirms that the expectations of accounting graduates as a result of Industry 4.0 emphasise the need for greater soft skills development (Burrows 2017; IFAC 2015, 2017; Schwab 2016; Strauss 2016; TT 2014). As a result, the requirements for these skills have been stipulated by the International Accounting Education Standards Board (IAESB). The IAESB has produced International Education Standard 3 (IES 3) which deals with such skills (IFAC 2015, 2017). It also highlights the importance of the nature and definition of such skills.

The importance of soft skills is also recognised by the American Institute of Certified Public Accountants (AICPA) in its publication, The Core Competency Framework for Entry into the Accounting Profession (AICPA 2010). This publication responded to the historic expectations and requirements for entry-level accountants' soft skills. The latter is but one example of many international trends where professional accounting bodies develop new competency frameworks (Jackling \& De Lange 2009).

\section{Study framework}

Globally, there are several skill frameworks provided by governments, business communities, professional bodies and academics (Tan \& Laswad 2018). For example, in Australasia, the Australian Qualifications Framework (AQF) and the New Zealand Qualifications Framework (NZQF) articulate the standards for qualifications in Australia and New Zealand in terms of the skills required for entry-level accountants. To ensure that South Africa (as a developing country) remains competitive in the global knowledge-based economy, the South African Qualifications Authority (SAQA) identified a framework to ensure that aspirant CAs(SA), amongst others, develop the necessary soft skills (SANQA 2012). These skills, applied at the highest level of proficiency and combined with specific competencies, form a vital relationship which results in a value-adding competence that is unique to the CA(SA) profession (SAICA 2014).

As with numerous accounting professions, South Africa has its own framework which specifically deals with the competencies of the CA(SA) profession. The SAICA's competency framework specifically emphasises the development of soft skills (SAICA 2014). Hence, entry-level CAs(SA) should have acquired soft skills during the SAICA qualification process through, amongst others, a university accounting programme (SAICA 2014).

The IAESB of the IFAC historically reviewed its standard on skills to meet the challenges of the changing business world in which professional accountants work and function (IFAC 2017). Hence, the IES 3 Initial Professional Skills was drafted, which came into effect on 01 July 2015 (Tan \& Laswad 2018). The standard identifies five skills: (1) intellectual, (2) technical and functional, (3) personal, (4 interpersonal and communication and (5) organisational. A charted accountant (CA) is required to integrate the latter with technical competence (typically acquired through a university accounting programme) and professional values, ethics and attributes in order to demonstrate professional competence. O'Connell et al. (2015) consider that accounting education (the accounting programme) is primarily responsible for, amongst others, the initial professional development of CAs (i.e. professional competence).

The WEF predicts the 'top 10 skills [for entry-level/aspirant CA(SA)'s] to thrive in Industry 4.0 by 2020 ' as (1) complex problem-solving, (2) critical thinking, (3) creativity, (4) people management, (5) coordinating others, (6) emotional intelligence, (7) judgement and decision-making, (8) service orientation, (9) negotiation and (10) cognitive flexibility (World Economic Forum 2016). Although the mix of soft skills required by Industry 4.0 is not significantly different from the WEF's 2015 predictions, the importance accorded to each skill has shifted. Hence, well-developed soft skills have become increasingly more important in the accountancy profession, especially in meeting the demands of Industry 4.0. For example, in 2015, critical thinking was considered the fourth most important skill for a professional accountant, whereas by 2020 the WEF predicts that this skill will move up to the second place. Creativity is also predicted to move up to third place, whereas in 2015 it was in 10th place. Emotional intelligence is also expected to rise in prominence as it appears to have never been a skill expected from accountants. Complex problem-solving still remains the most important soft skill for 2020.

It is clear that soft skills are regarded as crucial and directly linked to the career success of future professional accountants to be responsible business leaders. Various studies argue that 'accountancy education has failed to deliver suitably qualified entry-level accountants, who meet the expectations and requirements for entering the profession' (Jackling \& De Lange 2009:187). The latter is largely reflected in the belief that, historically, entry-level accountants did (Jackling \& De Lange 2009):

$[N]$ ot possess the important soft skills such as communication, life-long learning, teamwork, critical and strategic thinking, leadership and problem-solving skills in order to meet the expectations and requirements for newly qualified professional accountants. (p. 189)

As the founding member body of the Chartered Accountants' Group of Eight (CAGE), the SAICA (2014:10) defines the professional competence of a $\mathrm{CA}(\mathrm{SA})$ as 'the broad range of 
knowledge, skills, attitudes and behaviour that together account for the ability to deliver a specified professional service'. This includes (SAICA 2014):

[B] eing able to perform a particular task while applying, or brining to bear, the soft skills that are characteristic of CA(SA)'s to the level of proficiency defined as appropriate by the profession. (p. 8)

Hence, the SAICA's soft skills are 'the professional qualities and skills that all CAs are expected to bring to all tasks - the "how" of a CA's work' (SAICA 2014:8). These are categorised into three areas: (1) ethical behaviour and professionalism, (2) personal attributes and (3) professional skills (SAICA 2014). The SAICA does not prescribe to the accounting programme the level of proficiency to be achieved in soft skills as it acknowledges that some of these skills could be better taught during a period of practical experience prior to entering the profession (i.e. a traineeship in the 'real world of business') (SAICA 2014). Nonetheless, the accounting programme is held responsible for developing these skills. However, it is not clear what level of proficiency aspirant CAs(SA) should display in soft skills, specifically those demanded by Industry 4.0.

The SAICA's competency framework acknowledges the requirements for entry-level accountants entering the profession (SAICA 2014) and, more specifically, the changes that need to occur in response to Industry 4.0 (Olivier 2017). The SAICA's framework therefore highlights soft skills to address these requirements. In the current version, these include (1) problemsolving, (2) leadership, (3) professionalism, (4) strategic thinking, (5) time management, (6) verbal communication, (7) listening, (8) writing, (9) teamwork, (10) influencing others, (11) critical thinking and (12) ethical awareness (SAICA 2014; SANQA 2012; Viviers 2016). These qualities and skills, when applied at the highest level of proficiency and combined with specific competencies, form a vital relationship which results in a value-adding competence that is unique to the CA(SA) profession (SAICA 2014:8). As shown in Table 1, the SAICA competency framework sets out three different levels of proficiency to which soft skills can be developed. Because the SAICA framework is internationally recognised (Tan \& Laswad 2018), we use these three levels of proficiency as the benchmark to analyse the extent to which soft skills are perceived to be developed during a university accounting programme from the viewpoint of entry-level CAs(SA).

During the 1990s, Birkett (1993) developed a set of competencybased standards for professional accountants in Australia and New Zealand, which were ultimately adopted by the majority of accounting bodies in Australia and New Zealand (Certified Public Accountants Australia [CPA] Australia, Institute of Chartered Accountants Australia [ICAA] and the Institute of Chartered Accountants of New Zealand [ICANZ]). The SAICA, as the professional body for South African CAs (with a high global standing), is the founding member of the Global Accounting Alliance (GAA) and CAGE. Hence, the SAICA is well respected for ensuring the pre-eminence of the South African CA designation and is accordingly valued as a
TABLE 1: The meaning of South African Institute of Chartered Accountants' levels of proficiency used as a benchmark.

\begin{tabular}{|c|c|}
\hline Level & Description \\
\hline Level 1 & Not developed \\
\hline Level 2 & $\begin{array}{l}\text { Developed to the basic level of proficiency which requires an } \\
\text { awareness of the key ideas and principles within a specific area } \\
\text { of competence. Demonstration of technical expertise or detailed } \\
\text { knowledge in this area is not required. The candidate identifies and } \\
\text { explains the significance of the competency and the types of } \\
\text { circumstances in which it would arise or be applied. }\end{array}$ \\
\hline Level 3 & $\begin{array}{l}\text { Developed to the intermediate level of proficiency. At this level, the } \\
\text { candidate needs to demonstrate an understanding of the requirements } \\
\text { of the task and identify and apply the required professional skills, } \\
\text { including basic quantitative and qualitative analysis, to perform the } \\
\text { task on a preliminary basis (recognising that a review by more senior } \\
\text { staff may still be necessary). An intermediate understanding of the } \\
\text { subject matter is required. Complex calculations are not required. } \\
\text { Integration with other competencies is straightforward and is of limited } \\
\text { complexity. Level } 3 \text { includes Level } 2 \text { proficiency. }\end{array}$ \\
\hline Level 4 & $\begin{array}{l}\text { Developed to the advanced level of proficiency which requires a } \\
\text { candidate to complete all elements of a specified task successfully; } \\
\text { therefore, an advanced understanding of the subject matter is needed } \\
\text { Relevant soft skills and reflective capacity should be demonstrated at } \\
\text { the advanced level. Technical skills expected to be demonstrated at } \\
\text { this level include performing complex calculations and deciding on an } \\
\text { appropriate course of action. Proficiency at Level } 4 \text { is demonstrated } \\
\text { when the problem is clearly identified and thoroughly analysed or } \\
\text { when a situation is evaluated, and useful recommendations are made. } \\
\text { This level of proficiency includes proficiency levels } 2 \text { and } 3 \text {. }\end{array}$ \\
\hline
\end{tabular}

Source: South African Institute of Chartered Accountants (SAICA), 2014, Competency framework. Competencies of a CA (SA) at the point of the Initial Test of Competence (ITC) (assessment of core technical knowledge), viewed 10 January 2019, from https://www.saica. co.za/Portals/0/LearnersStudents/documents/Detailed Guidance tothe competency framework for the academic programme_Updated_and approvedJuly 2014.pdf

'trustworthy, reliable and internationally admired and recognised designation' (Oliver 2017).

The CAGE member bodies include, amongst others, NZICA and ICAA; as a result, the SAICA's competency framework also incorporates Birkett's (1993) taxonomy of professional (soft) skills, which classifies skills into two main groups: (1) cognitive and (2) behavioural. His taxonomy further identifies three dimensions of behavioural skills: (1) personal, (2) interpersonal and (3) organisational. Birkett (1993:148) also notes that 'professional work [such as that of a professional accountant] requires action, that is supported by decision processes. Accordingly, it involves exercise of instrumental skills, supported by intellectual skills'. He also suggests that both cognitive and behavioural skills are likely to 'parallel typical patterns of career progress'. Hence, 'initially drawing on technical and personal skills followed by analytical/constructive and interpersonal skills whilst appreciative and organisational skills surface at a more advanced career stage' (i.e. practical experience). (p. 150)

In summary, most competency frameworks applicable to the accountancy profession share some common elements regarding the basic or fundamental skills, people-related skills, conceptual or thinking skills, personal skills, and attributes and skills related to the 'real world of business' and community at large (Tan \& Laswad 2018) and are notably evident for the CAGE member bodies. However, Industry 4.0 will have a profound impact on such competency frameworks, incorporating or placing greater emphasis on the development of skills such as complex problem-solving, critical thinking, creativity, people management, coordinating others, emotional intelligence, judgement and decision-making, service orientation, emotional and cognitive flexibility. For this study, we refer to the requirements suggested by the WEF in its 2016 
Future World of Work report, IES 3 (2015) and the SAICA competency framework (2014), as these have identified a comprehensive list of skills which is internationally recognised. We therefore place specific emphasis on the development of aspirant or entry-level CA(SA)'s soft skills development as required by Industry 4.0 .

Additionally, we take into consideration the framework developed by Birkett (1993), which classifies 'soft skills' under two broad categories: (1) cognitive and (2) behavioural.

Cognitive skills are sub-categorised into two further dimensions:

- Routine/technical skills - described as following defined routines with some mastery (e.g. tasks to be performed are defined and performance involves exercising prefocused and pre-developed skills).

- Intellectual skills - a combination of Birkett's analytical and appreciative skills, relating to the ability to solve problems, make decisions and exercise professional judgement.

Behavioural skills are sub-categorised into three further dimensions:

- Personal skills - the ability to handle oneself in challenging, stressful or conflicting situations as well as situations exposed to time pressure and change (e.g. having a positive, proactive and reflective attitude about one's own performance).

- Interpersonal skills - involves the ability to achieve outcomes through interpersonal interactions (e.g. people skills, listening, empathy, communication, motivation, and team work and management).

- Organisational skills - entails the ability to achieve outcomes though the use of organisational networks (e.g. accessing and using power and culture, building and activating intra- and inter-organisational networks or representing an organisation).

Figure 1 shows the Industry 4.0 skills framework used in this study, based on the WEF's 2016 Future World of Work report, the SAICA's competency framework (2014) soft skills as well as the framework suggested by Birkett (1993).

It is important to note that this study does not include the development of aspirant CA(SA)'s technical skills in accountancy depicted by Birkett's (1993) taxonomy, specifically dealing with routine/technical skills. This is because the focus of this study is on the development of entry-levelCA(SA)'s soft skills during a university accounting degree, that is, accounting programme.

\section{Research methodology Research method}

The research questions were addressed by following a twopronged approach. Firstly, a literature review was performed exploring Industry 4.0 and its impact on the education of aspirant $\mathrm{CAs}(\mathrm{SA})$ as well as the changes in the required skills set of future generation professional accountants. Accordingly, it was revealed in the framework of the study that a university accounting programme should focus more on the development of soft skills as these are the skills demanded by Industry 4.0. It was further determined that the current accounting programme fails to deliver entry-level CAs(SA) who display competence in soft skills.

\section{Data collection}

A questionnaire was used to gather data. This method is supported by Henning, Van Rensburg and Smit (2004:3, as quoted in Marx 2008:cccIxxiv) who emphasise the 'importance of capturing the perceptions of subjects in a population' in response to a research question. A questionnaire was regarded as the most appropriate research instrument, primarily because of the large population anticipated for the empirical work. This choice is supported by Coetzee (2004:7.2), who states that a 'questionnaire entails a large number of respondents answering a set of questions, with the aim of obtaining their perceptions pertaining to a research problem'. Questionnaires are also described as the 'interface between the respondent and the researcher' (Anon 2009). They are used to 'obtain information about prevailing conditions in a planned way' (Behr 1988, as quoted in Thomas 2000:33). They also give information on 'what a subject knows' (Creswell 2013; Kleinbaum \& Klein 2012; Miles, Huberman \& Saldana 2014; Salant \& Dillman 1994, as quoted in Hulsart 2002:52).

Because of the high standing of the SAICA's Assessment of Professional Competence (APC - the final assessment prior to aspirant $\mathrm{CA}(\mathrm{SA})$ 's entering the CA(SA) profession) (SAICA 2017) as well as the SAICA's support of this study, the questionnaire was distributed to all entry-level accountants in South Africa who successfully completed the SAICA November 2016 APC. Accordingly, the target population consisted of the 2247 students who passed the November 2016 APC. It was assumed that this cohort would have a sound grasp of what would be expected from them to demonstrate professional competence in terms of the SAICA's soft skills, as these are assessed as part of the APC. It was thus accepted by the researchers that 'respondents would exercise the necessary diligence and due care in completing the questionnaire' (Marx 2008:cccIxxxii) as these respondents could be described as 'a group of individuals who have one or more characteristics in common, that are of interest to the researchers' (Best \& Kahn 1998:12, as quoted in Hulsart 2002:53).

Teaching soft skills includes the 'use of appropriate Information Technology software tools' (SAICA 2014). The use of ordinary mail, telephone or facsimile to distribute the questionnaire could therefore be perceived as being 'old fashioned'. Most entry-level CAs(SA) are assumed to have access to work email and/or a personal email address. This assumption is made because the SAICA provides details regarding the SAICA APC to candidates by means of email 


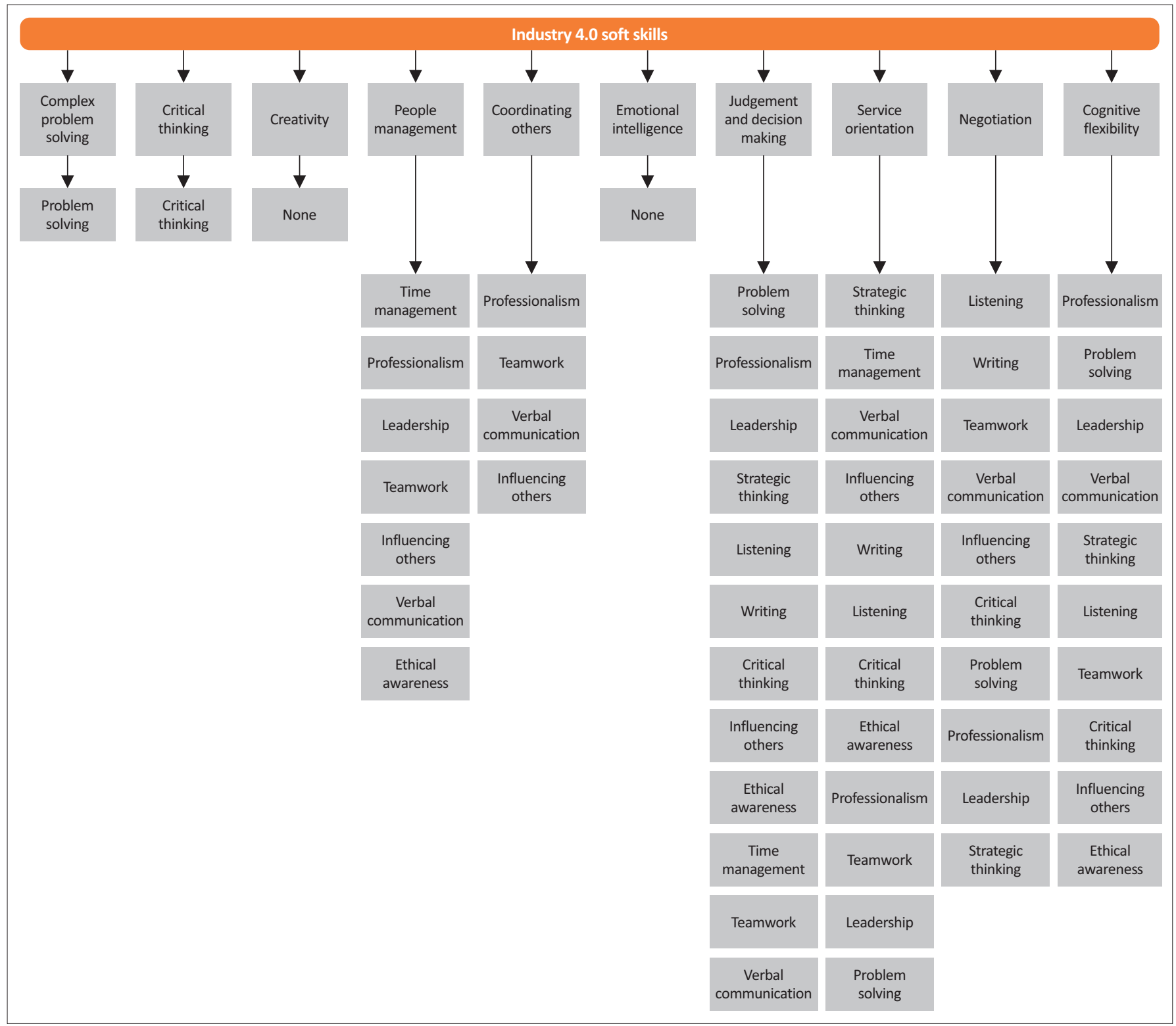

FIGURE 1: Industry 4.0 skills framework.

communication. The researchers therefore used email to distribute the questionnaire to the target population. The email distribution method contained a link to a website, where the questionnaire could be answered, and the data could be recorded. Ethics approval was obtained from the University of Johannesburg. The SAICA distributed the questionnaire on behalf of the researchers. An independent statistical consultant was appointed to create a website and control the online administration and recording of the data as well as validating the accuracy of the statistical analysis and interpretations.

The use of a questionnaire as a method of gathering data is sometimes discouraged as it could result in a low response rate (Creswell et al. 2007:157; Mouton 2001:153). This study yielded a response rate of $40.77 \%$. Marx (2008) asserts that questionnaire response rates in South Africa generally range between $25 \%$ and $38 \%$. As a result, the response rate achieved for this research $(40.77 \%)$ was deemed to be acceptable when compared to the benchmark suggested by Marx (Marx 2008 as quoted in Brewer 2001; Hadden 2002; Weiss 2005). The response rate of this research therefore contributes to the reliability and usefulness of the information. Additionally, it could also be interpreted as confirming the importance of soft skills, based on the perception of entry-level CAs as summarised in Table 2.

\section{Analysis}

We used IBM Statistical Package for the Social Sciences (SPSS) version 24, a statistical analysis software package, to generate the frequency and mean analysis. Accordingly, descriptive statistical analysis was performed to address research question 1: 'are entry-level CAs(SA) aware of the required soft skills in terms of Industry 4.0?'

Research question 2, 'what are entry-level CA(SA)'s perceptions of the role which a university accounting programme plays in 
TABLE 2: Response rate.

\begin{tabular}{lcc}
\hline Description & Number & $\%$ \\
\hline Target population (Total) & 2247 & 100.00 \\
Received & 916 & 40.77 \\
Partially completed & 0 & 0.00 \\
Not completed & 1331 & 59.23 \\
\hline
\end{tabular}

developing the Industry 4.0 soft skills?', was approached by analysing descriptive frequencies and mean analysis. An exploratory factor analysis was performed to refine the soft skills included in this study into the categories proposed by Birkett (1993), as used in the framework of the study. Accordingly, research questions 3 and 4 could be addressed through inferential statistical analysis, that is, (1) an exploratory cluster analysis and multivariate analysis of variance (MANOVA) in order to determine the impact of various independent variables on the development of the soft skills (i.e. dependent variable). The MANOVA was considered the most appropriate tool (Crichton, Playfoot \& Adams 2014; Everitt et al. 1991) as we were particularly interested in the interrelationship between the independent variables in the study.

\section{Ethical considerations}

This article followed all ethical standards for a research without direct contact with human or animal subjects.

\section{Results and discussion}

This section discusses the results of the study. It firstly explores respondents' awareness about the soft skills required by Industry 4.0 and the role which the accounting programme is perceived to play within this context. This is followed by a discussion of the extent to which the soft skills are being developed, using the SAICA's levels of proficiency as a benchmark (see Table 1). Consequently, recommendations are made for possible improvements to address the current shortfall of entry-level CAs(SA) with well-developed soft skills.

\section{Awareness of entry-level chartered accountants in South Africa about the soft skills required by Industry $\mathbf{4 . 0}$}

Our findings showed that all respondents were aware of the need for well-developed soft skills in order to be successful in today's changing world of business. However, only $58.50 \%$ of respondents were aware of the impact of Industry 4.0 on their future world of work. A large proportion of respondents $(41.50 \%)$ were unaware of the specific soft skills demanded by Industry 4.0, while those who were aware stated that it was only during their practical experience (in the form of a traineeship) that this awareness was created. Hence, it can be concluded that the awareness of the soft skills was not created by the university accounting programme.

The findings also suggested that the accounting programme could improve on the way it develops soft skills. This is because only $58.52 \%$ of respondents indicated that it was the accounting programme which made them aware of the soft skills specific to the SAICA competency framework. Moreover, the majority of respondents (51.09\%) stated that the accounting programme only played a moderate role in developing soft skills. A small percentage of respondents $(9.17 \%)$ viewed the accounting programme as playing a crucial role in this regard. This is explained by most respondents $(66.81 \%)$ considering their practical experience (in the form of a traineeship) as playing a crucial role instead. These findings appear to be generally in line with what various authors have suggested, that is, practical experience is more effective to develop soft skills.

Based on the aforementioned discussion, this study makes the following recommendations:

- Accounting programme providers should place greater focus on making aspirant CAs(SA) aware of the importance of developing soft skills effectively, as stipulated in an accountancy professional body's competency framework

- Accounting programme providers should place greater focus on making aspirant CAs(SA) aware of Industry 4.0, and specifically its impact on their future world of work.

\section{The development of Industry $\mathbf{4 . 0}$ soft skills}

Table 3 shows that the development of time management dominates the development of the 14 soft skills investigated in this study, as the average level of proficiency is the highest (mean $=3.34)$. This is because the majority of respondents $(48.47 \%)$ indicated that the university accounting programme developed their time management skills to the advanced level of proficiency. Accordingly, these respondents could complete all the elements of time management successfully, as per the benchmark in Table 1. The mean (3.34) also shows that the overall group of respondents perceived time management to be developed to the intermediate level of proficiency. This is because the mean appears to be closer to 3 (i.e. the intermediate level of proficiency). This therefore demonstrates an understanding of the requirements to effectively manage time or not being able to manage it without guidance or mentoring.

Both creativity and emotional intelligence appear to be the least developed skills (mean for both these skills $=1.49$ ). This is because of the majority of respondents stated that these skills were not developed by the university programme. In both cases, $50.97 \%$ of respondents indicated that these skills were not developed, whereas the remainder $(49.02 \%)$ were of the opinion that these were only developed to the basic level of proficiency (Level 2 - see Table 1). It is interesting to note that there is a correlation between the development of creativity and emotional intelligence. This is because respondents who selected the basic level of proficiency for creativity made the same selection for emotional intelligence and vice versa $(p<0.05)$. The inverse is also true, that is, respondents who stated that the university accounting programme did not develop their creativity indicated the same for the development of their emotional intelligence $(p<0.05)$.

Complex problem-solving, listening and critical thinking were perceived to be developed to the intermediate level of proficiency $($ mean $=3.06$ for each of the three skills). For 
TABLE 3: Extent to which entry-level chartered accountants in South Africa perceive the development of soft skills during a university accounting programme - Frequency and percentage per level of proficiency as well as the mean for respondent population.

\begin{tabular}{|c|c|c|c|c|c|c|c|c|c|}
\hline \multirow[t]{2}{*}{ Soft skill } & \multicolumn{2}{|c|}{ Advanced } & \multicolumn{2}{|c|}{ Intermediate } & \multicolumn{2}{|c|}{ Basic } & \multicolumn{2}{|c|}{ Not at all } & \multirow[t]{2}{*}{ Mean } \\
\hline & $\mathrm{FQ}+$ & $\%$ & $\mathrm{FQ}+$ & $\%$ & $\mathrm{FQ} \dagger$ & $\%$ & $\mathrm{FQ}+$ & $\%$ & \\
\hline Problem-solving & 284 & 31.00 & 428 & 46.72 & 176 & 19.21 & 28 & 3.06 & $3.06 *$ \\
\hline Leadership & 24 & 2.62 & 188 & 20.52 & 412 & 44.98 & 292 & 31.88 & $1.94 *$ \\
\hline Professionalism & 80 & 8.73 & 252 & 27.51 & 360 & 39.30 & 224 & 24.45 & $2.21 *$ \\
\hline Strategic thinking & 232 & 25.33 & 408 & 44.54 & 212 & 23.14 & 64 & 6.99 & $2.88^{*}$ \\
\hline Time management & 444 & 48.47 & 376 & 41.05 & 64 & 6.99 & 32 & 3.49 & $3.34 *$ \\
\hline Verbal communication & 100 & 10.92 & 312 & 34.06 & 352 & 38.43 & 152 & 16.59 & $2.39 *$ \\
\hline Listening & 332 & 36.24 & 360 & 39.30 & 168 & 18.34 & 56 & 6.11 & $3.06 *$ \\
\hline Writing & 408 & 44.54 & 384 & 41.92 & 108 & 11.79 & 16 & 1.75 & $3.29 *$ \\
\hline Team work & 96 & 10.48 & 248 & 27.07 & 328 & 35.81 & 244 & 26.64 & $2.21 *$ \\
\hline Influencing others & 60 & 6.55 & 172 & 18.78 & 368 & 40.17 & 316 & 34.50 & $1.97 *$ \\
\hline Critical thinking & 308 & 33.62 & 396 & 43.23 & 168 & 18.34 & 44 & 4.80 & $3.06 *$ \\
\hline Ethical awareness & 80 & 8.73 & 252 & 27.51 & 360 & 39.30 & 224 & 24.45 & $2.21 *$ \\
\hline Creativity & - & - & - & - & 449 & 49.02 & 467 & 50.98 & $1.49 *$ \\
\hline
\end{tabular}

$\dagger$, Frequency of 'yes' for a particular level of proficiency (extent).

$*, p<0.05$.

complex problem-solving, which is the most important soft skill in terms of Industry 4.0, the majority of respondents (46.72\%) indicated that their ability to solve complex problems was developed to the intermediate level of proficiency. Some respondents $(31 \%)$, however, indicated that this skill was developed to the advanced level. Only 3.06\% considered that the accounting programme had not developed their complex problem-solving skills at all. The majority of respondents (39.30\%) viewed the university accounting programme as developing their ability to listen to the intermediate level of proficiency, whereas $43.23 \%$ were of the opinion that their ability to think critically was developed to the intermediate level. Only $36.24 \%$ and $33.62 \%$, respectively, indicated that such a programme developed their ability to listen and think critically to the advanced level of proficiency.

\section{Refining the development of Industry 4.0 soft skills: Evidence from an exploratory factor analysis}

An exploratory factor analysis was conducted on the soft skills included in this research using maximum likelihood extraction and direct oblimin rotation to determine the unidimensionality of each of these skills. Hence, exploratory factor analysis explored and identified similar behaviour of the individual soft skills included in the total data set (Field 2013).

The appropriateness of performing an exploratory factor analysis was determined with reference to the Kaiser-MeyerOlkin (KMO) measure of sampling adequacy and Bartlett's test of sphericity. It indicated that the data applicable to the development of soft skills were appropriate for exploratory factor analysis because the KMO was 0.878 , which is above the benchmark of 0.6 , while Bartlett's test of sphericity was 0.000 (i.e. $p<0.05$ ) (Field 2013).

The question remains whether the soft skills included in this research were unique and consequently form specific factors. Table 4 shows that the soft skills included in this research were represented by three factors (i.e. constructs/themes) based on the eigenvalue criterion (eigenvalue $>1$ ) (Field 2013).
This indicated that a mix of soft skills included in this research was associated with similar behaviour in the data and that their behaviours were not unidimensional. Accordingly, each of the three factors appeared to be unique and, hence, each skill was represented by a specific factor (i.e. a specific construct/theme) as indicated in Table 4.

Soft skills relating to professionalism, ethical awareness, creativity and emotional intelligence resulted in a combination of similar responses. As shown in Table 3, the frequency regarding the level of proficiency and mean for both professionalism and ethical awareness were similar. Consequently, the respondents regarded both professionalism and ethical awareness as being developed to the basic level of proficiency (Level 2 - see Table 1). This was also evident for creativity and emotional intelligence. The frequencies and mean scores for both these skills were similar (see Table 3). Hence, when performing the exploratory factor analysis, identical variables resulted in an error. The error indicates that the correlation matrix was non-positive definite (NPD), that is, some of the eigenvalues of the correlation matrix were not positive numeric characters (numbers) (Field 2013). This means that at least one redundant variable was evident and applicable to the exploratory analysis (Field 2013).

Identification through correlation and descriptive analysis (see Table 3) indicates that a combination of the skills (variables) related to professionalism, ethical awareness, creativity and emotional intelligence had identical responses. Hence, at least one variable in each of these combinations was considered redundant. This results in one 'redundant skill' in each of the two combinations to be excluded from the factor analysis, and instead to be interpreted based on frequency and mean, that is, on a descriptive basis (see Table 3). The decision was made to exclude both ethical awareness and emotional intelligence from the factor analysis variable set. The exploratory factor analysis therefore only included 12 of the soft skills included in this research, as indicated in Table 4. 
Table 4 shows that the communality extraction value for listening was 0.754 . Hence, the ability to listen correlates strongly with the overall factor analysis structure. In fact, all the soft skills except for creativity correlated well with the extraction method to formulate the three factors (see Table 5). This is because each of these soft skills (except for creativity) had a communality extraction greater than 0.3 (Field 2013). Creativity did not correlate with the overall factor structure as the communality extraction value was significantly below the benchmark of 0.3 . This is confirmed as most (50.98\%) of the respondents indicated that their ability to be creative was not developed by the university accounting programme, whereas $49.02 \%$ were of the opinion that it was only developed to Level 2, the basic level of proficiency (see Table 3).

As evident from Table 5, the Cronbach's alpha coefficient values were above the acknowledged threshold of 0.7 (Field 2013), justifying the reliability of each construct (i.e. factor) as satisfactory. Factor 1 explained approximately $43.306 \%$ of the variance of the five variables included therein (i.e. leadership, professionalism, verbal communication, team work and the ability to influence others), whereas all three factors in combination explained approximately $65.08 \%$ of the total variance in the data set for the 12 soft skills included in the factor analysis. Hence, this reflected the extent to which respondents viewed the development of soft skills during a university accounting programme.

The factor analysis showed that Factor 1 consisted of leadership, professionalism, verbal communication, team

TABLE 4: Communalities of each soft skill in the factor analysis.

\begin{tabular}{lc}
\hline Soft skill & Communality extraction \\
\hline Problem-solving & 0.480 \\
Leadership & 0.731 \\
Professionalism & 0.571 \\
Strategic thinking & 0.699 \\
Time management & 0.357 \\
Verbal communication & 0.533 \\
Listening & 0.754 \\
Writing & 0.610 \\
Team work & 0.632 \\
Influencing others & 0.692 \\
Critical thinking & 0.602 \\
Creativity & 0.004 \\
\hline
\end{tabular}

work and the ability to influence others, whereas Factor 2 was made up of skills relating to time management and ability to listen and write. Lastly, Factor 3 consisted of problem-solving skills as well as the ability to think strategically and critically. The skill relating to creativity did not load onto any of the factors and could be ascribed to the low communality extraction of 0.004 as shown in Table 4 .

We used Birkett's (1993) taxonomy to label each factor (construct/theme) from the exploratory factor analysis (see the 'Study framework' section). Hence, each factor was grouped into one of the two categories suggested by Birkett (1993): (1) cognitive skills or (2) behavioural skills. We further categorised each factor based on Birkett's (1993) sub-categories for cognitive skill (technical or intellectual skills) and behavioural skills (personal skills, interpersonal skills or organisational skills). This research does not focus on the technical skills developed by a university accounting programme. As such these are not included in the grouping of factors 1, 2 and 3. Factor 3 consists of soft skills relating to the ability to solve problems, think strategically and the ability to think critically. Hence, applying Birkett's (1993) taxonomy, these skills represent the cognitive intellectual skills of an entrylevel CA(SA) (see the 'Study framework' section). Accordingly, Factor 3 was labelled as respondents' cognitive intellectual skills (intellectual skills). Both factors 1 and 2 contained soft skills that related to different categories suggested by Birkett (1993). For example, according to Birkett (1993), leadership is a behavioural skill which is sub-categorised as an organisational skill. Leadership forms part of Factor 1 (construct); however, this construct also contains soft skills which relate to, for example, Birkett's (1993) interpersonal skills.

Leadership, professionalism, verbal communication, teamwork and the ability to influence others all form constructs of Factor 1 and in effect represent 'skills which entail the ability to secure outcomes through the use of organisational networks' (e.g. accessing and using power and culture, building and activating intra- and inter-organisational networks, and representing an organisation). Hence, Factor 1 is labelled as respondents' behavioural organisational skills (organisational skills).

The same applies to the labelling of Factor 2. For example, Factor 2 consists of soft skills relating to respondents'

TABLE 5: Exploratory factor analysis outputs.

\begin{tabular}{|c|c|c|c|c|c|}
\hline Description of factor & $\%$ variance explained & Eigenvalue & Number of factors & Cronbach's alpha & Factor load \\
\hline $\begin{array}{l}\text { Factor 1: Organisational skills } \\
\text { - Leadership } \\
\text { - Professionalism } \\
\text { - Verbal communication } \\
\text { - Team work } \\
\text { - Influencing others }\end{array}$ & $\begin{array}{c}43.306 \\
- \\
- \\
- \\
- \\
-\end{array}$ & $\begin{array}{c}5.197 \dagger \\
- \\
- \\
- \\
- \\
-\end{array}$ & $\begin{array}{l}1 \\
- \\
- \\
- \\
-\end{array}$ & $\begin{array}{c}0.879 \$ \\
- \\
- \\
- \\
- \\
-\end{array}$ & $\begin{array}{l}- \\
0.888 \\
0.631 \\
0.618 \\
0.767 \\
0.888\end{array}$ \\
\hline $\begin{array}{l}\text { Factor 2: Personal and interpersonal skills } \\
\text { - Time management } \\
\text { - Listening } \\
\text { - Writing }\end{array}$ & $\begin{array}{l}55.848 \\
- \\
- \\
-\end{array}$ & $\begin{array}{c}1.505 \dagger \\
- \\
- \\
-\end{array}$ & $\begin{array}{l}1 \\
- \\
- \\
-\end{array}$ & $\begin{array}{c}0.763 \$ \\
- \\
- \\
-\end{array}$ & $\begin{array}{l}- \\
0.476 \\
0.840 \\
0.773\end{array}$ \\
\hline $\begin{array}{l}\text { Factor 3: Intellectual skills } \\
\text { - Problem-solving } \\
\text { - Strategic thinking } \\
\text { - Critical thinking }\end{array}$ & $\begin{array}{c}65.088 \\
- \\
- \\
-\end{array}$ & $\begin{array}{c}1.109 \dagger \\
- \\
- \\
-\end{array}$ & $\begin{array}{l}1 \\
- \\
- \\
-\end{array}$ & $\begin{array}{c}0.807 \$ \\
- \\
- \\
-\end{array}$ & $\begin{array}{l}- \\
0.575 \\
0.810 \\
0.636\end{array}$ \\
\hline
\end{tabular}

$\$$, Above the threshold of 0.7 , hence reliability is considered satisfactory. 


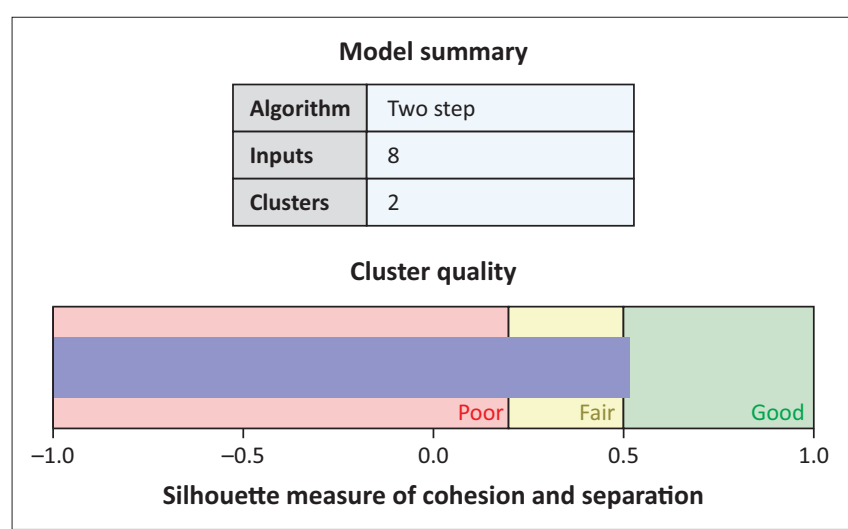

FIGURE 2: Silhouette measure of cohesion and separation of the differen clusters based on the extent to which entry-level chartered accountants perceive soft skills to be developed by a university accounting programme.

ability to manage their time and to listen and write. However, time management is regarded by Birkett (1993) as a personal skill, whereas the ability to write and listen is interpersonal skill. Accordingly, we labelled Factor 2 as respondents' behavioural personal and interpersonal skills (personal and interpersonal skills).

\section{Identifying the influences on the development of Industry 4.0 soft skills: Evidence from a two-step cluster analysis}

In the next step, we performed a two-step cluster analysis to further examine, by means of clusters, the extent to which the three factors identified in this research were perceived to be developed by a university accounting programme. Hence, the cluster analysis was an explorative analysis technique that attempted to identify structures within the data for further analysis. The purpose of a cluster analysis is to maximise heterogeneity between segments (Hair et al. 2010; Yong \& Pearce 2013). It therefore performs the task of grouping a set of objects in such a way that clusters can be readily identified as similar to each other (i.e. comparable). Figure 2 shows the preclustering with reference to the hierarchical method. From this research two clusters were evident. The cluster quality was reported through the silhouette measure of cohesion and separation that was acceptable when compared to the benchmark of 0.3 (Yong \& Pearce 2013).

The cluster analysis provided a solution of two clusters, with $58.50 \%$ (536) of respondents grouped into cluster 1 and $41.50 \%$ (380) grouped into cluster 2. Accordingly, all respondents were clustered into either cluster 1 or 2 and showed similar characteristics within each of the clusters for the respondent population. The hierarchical output for the cluster analysis is shown in Table 6.

As shown in Table 6, respondents' awareness of the soft skills required by Industry 4.0 was regarded as the most important predictor for both clusters 1 and 2, whereas respondents' gender was the least important. Table 6 also shows that there is a definite difference in the extent to which both clusters perceived the factors included in this research (i.e. organisational skills, personal and interpersonal skills and intellectual skills) to be developed by a university accounting programme. For all three factors, cluster 2 (respondents who were not aware of the soft skills required by Industry 4.0) indicated a lesser extent to which these respondents perceived the university accounting programme to have developed their organisational (Factor 1), personal and interpersonal (Factor 2) and intellectual (Factor 3) skills. Therefore, the level of perceived proficiency can be explained by the awareness of Industry 4.0 and its required soft skills, demographic information and the role which a university accounting programme is perceived to play in developing soft skills. Accordingly, a MANOVA was performed to determine whether these elements could have an influence on the development of respondents' organisational, personal and interpersonal as well as intellectual skills (i.e. the three factors identified in this research).

\section{Evidence from the multivariate analysis}

The cluster analysis suggested that the perceived level of proficiency could be explained by the awareness of Industry 4.0 and its required soft skills as well as some demographic information and the role which a university accounting programme was perceived to play in their development. Hence, we used MANOVA as an inferential statistical analysing tool to explore the effect of the key identified variables (i.e. independent variables from the cluster analysis in Table 6) on the extent of development of respondents' organisational (Factor 1), personal and interpersonal (Factor 2) and intellectual (Factor3) soft skills (dependent variables). Wealso explanatively determined the possible interactive effects in explaining the variance into the extent to which respondents' skills were developed with reference to the key independent variable.

Multivariate analysis was regarded as the appropriate analysis as the alternative to a one-way analysis of variance (ANOVA). This is because we were specifically interested in the interactive effects of the independent variables on the extent to which respondents viewed a university accounting programme to develop soft skills (Everitt et al. 1991).

The focus of the identification of meaningful effects was based on the Wilks' lambda $(\lambda)$ and its statistical significance in conjunction with the partial eta-squared value. Although the Pillai-Bartlett criterion is considered the most robust and powerful test statistic, the Wilks' lambda was used as it was able to provide an indication of the variance not accounted for by the combined dependent variables, with the difference $(1-\lambda)$ representing the variance that is accounted for by the best linear combination of the dependent variables, which enables the explorative understanding of the key effects on the development of respondents' organisational (Factor 1), personal and interpersonal (Factor 2) and intellectual (Factor 3) soft skills.

Table 7 shows the $\lambda$ value for each of the independent variables included to explore the impact on the development of entrylevel CAs' soft skills as well as their significance. Accordingly, it 
Table 6: Outputs from two-step cluster analysis

\begin{tabular}{|c|c|c|c|c|c|c|}
\hline Cluster & Yes & No & Moderate & Mean & $\%$ & $n$ \\
\hline \multicolumn{7}{|l|}{ 1: Respondents are aware of the soft skills required by Industry 4.0} \\
\hline Size & - & - & - & - & 58.5 & 536 \\
\hline Awareness of Industry 4.0 and impact on soft skills demanded (\%) & 100 & - & - & - & - & - \\
\hline Industry 4.0 soft skills' awareness created by university accounting programme (\%) & 100 & - & - & - & - & - \\
\hline Role of university accounting programme in developing soft skills demanded by Industry $4.0(\%)$ & - & - & 53 & - & - & - \\
\hline Factor & - & - & - & - & - & - \\
\hline Factor 2: Extent of development of personal and interpersonal skills & - & - & - & 3.34 & - & - \\
\hline Factor 3: Extent of development of intellectual skills & - & - & - & 3.09 & - & - \\
\hline Factor 1: Extent of development of organisational skills & - & - & - & 2.23 & - & - \\
\hline Gender & - & - & - & - & - & - \\
\hline Male & - & - & - & - & 53.7 & - \\
\hline Female & - & - & - & - & - & - \\
\hline \multicolumn{7}{|l|}{ 2: Respondents are not aware of the soft skills required by Industry 4.0} \\
\hline Awareness of Industry 4.0 and impact on soft skills demanded (\%) & - & 100 & - & - & - & - \\
\hline Role of university accounting programme in developing soft skills demanded by Industry $4.0(\%)$ & - & - & 48.4 & - & - & - \\
\hline Factor & - & - & - & - & - & - \\
\hline Factor 2: Extent of development of personal and interpersonal skills & - & - & - & 3.07 & - & - \\
\hline Factor 3: Extent of development of intellectual skills & - & - & - & 2.87 & - & - \\
\hline Factor 1: Extent of development of organisational skills & - & - & - & 2.03 & - & - \\
\hline Gender & - & - & - & - & - & - \\
\hline Male & - & - & - & - & - & - \\
\hline Female & - & - & - & - & 55.8 & - \\
\hline
\end{tabular}

TABLE 7: The individual Wilks' lambda $(\lambda)$ value for the independent variables included in the multivariate analysis of variance to explore the effect on the development of respondents' organisational, personal and interpersonal as well as intellectual skills.

\begin{tabular}{|c|c|c|c|c|c|}
\hline \multirow[t]{2}{*}{ Description of independent variable } & \multicolumn{5}{|c|}{ Multivariate test results } \\
\hline & Value $(\lambda)$ & $\boldsymbol{F}$ & Sig. & Partial eta-squared & Variance explained $(1-\lambda)$ \\
\hline Gender & 0.977 & 6.832 & $0.000 *$ & 0.023 & 0.023 \\
\hline Awareness of Industry 4.0 and impact of soft skills demanded & 0.944 & 17.029 & $0.000^{*}$ & 0.056 & 0.056 \\
\hline Industry 4.0 soft skills' awareness created by university accounting programme & 0.978 & 6.582 & $0.000^{*}$ & 0.022 & 0.022 \\
\hline Role of university accounting programme in developing soft skills demanded by industry 4.0 & 0.882 & 12.322 & $0.000 *$ & 0.041 & 0.118 \\
\hline
\end{tabular}

Role of university accounting programme in developing soft skills demanded by industry 4.0

$0.882 \quad 12.322 \quad 0.000$

$*, p<0.05$.

appears that respondents' perceptions regarding the development of soft skills explained the highest percentage of the variance (approximately 11.80\%) of all independent variables in combination. This reflected the extent (level of proficiency) to which respondents perceived the university programme to develop their soft skills (dependent variables). The latter was regarded as statistically significant $(p<0.05)$. Whether or not respondents were made aware of Industry 4.0 by a university accounting programme seems to explain only $2.20 \%$ of the variance to which respondents viewed the programme to develop their skills (i.e. extent). Although, smaller when compared to the role which such a programme has to develop soft skills, the impact was regarded as meaningful (statistically significant $-p<0.05$ ). In fact, our research suggests that all the independent variables evident from our cluster analysis (see Table 7) are statistically significant (meaningful) regarding the extent of a university accounting programme's ability to develop soft skills $(p<0.05)$.

Our research further reveals that the majority of respondents were aged between 26 and 30 years (50.70\%). For all three categories of soft skills (i.e. organisational, personal and interpersonal, and intellectual), gender appears to affect the extent to which respondents perceived these skills to be developed $(p<0.05)$. Approximately $50.22 \%$ of respondents were female, whereas the remainder (approximately 49.78\%) were male.

The majority of respondents (58.50\%) were aware of Industry 4.0 and its impact on their soft skills. Room for improvement was evident as a large proportion of respondents (41.50\%) were not aware of such an impact. However, Table 8 shows that such an awareness did not impact the development of respondents' soft skills related to time management, the ability to listen and write (personal and interpersonal skills), complex problem-solving as well as their ability to think strategically and critically (intellectual skills) $(p>0.05)$. Respondents' organisational skills (such as leadership, professionalism, verbal communication, teamwork and the ability to influence others) appear not to be influenced by the awareness of Industry 4.0, its impact on the future world of work or its consequent demands on respondents' soft skills $(p>0.05)$.

Most of the respondents (51.10\%) indicated that a university accounting programme played a moderate role in developing the soft skills demanded by Industry 4.0 , whereas $23.10 \%$ of respondents stated that such a programme had a significant role. Only $9.20 \%$ were of the opinion that the programme played a crucial role in this regard, whereas $16.60 \%$ believed 
Table 8: MANOVA test results - Impact of independent variables on organisational (factor 1), personal and interpersonal (factor 2) and intellectual (factor 3) skills Description of independent variable Soft Skill (dependent variable)

\begin{tabular}{|c|c|c|c|c|c|c|c|c|c|}
\hline & \multirow{2}{*}{\multicolumn{3}{|c|}{$\begin{array}{c}\text { Organisational Skills } \\
\text { (Factor 1) }\end{array}$}} & \multirow{2}{*}{\multicolumn{3}{|c|}{$\begin{array}{l}\text { Personal and Interpersonal Skills } \\
\text { (Factor 2) }\end{array}$}} & \multirow{2}{*}{\multicolumn{3}{|c|}{$\begin{array}{l}\text { Intellectual Skills } \\
\text { (Factor 3) }\end{array}$}} \\
\hline & & & & & & & & & \\
\hline & $\mathbf{F}$ & Sig. & $R$-Squared & $\mathbf{F}$ & Sig. & R-Squared ${ }^{\$}$ & $\mathbf{F}$ & Sig. & R-Squared $\$$ \\
\hline Gender & 11.155 & $0.001 *$ & 0.013 & 16.302 & $0.000 *$ & 0.018 & 11.841 & $0.001 *$ & 0.013 \\
\hline $\begin{array}{l}\text { Awareness of Industry } 4.0 \text { and its impact of soft } \\
\text { skills demanded }\end{array}$ & 0.985 & $0.321 \#$ & 0.001 & 10.02 & $0.002 *$ & 0.011 & 11.314 & $0.001 *$ & 0.013 \\
\hline $\begin{array}{l}\text { Industry } 4.0 \text { soft skills' awareness created by } \\
\text { university accounting programme }\end{array}$ & 2.154 & $0.143 \#$ & 0.002 & 4.709 & $0.030 *$ & 0.005 & 18.792 & $0.000 *$ & 0.021 \\
\hline $\begin{array}{l}\text { Role of university accounting programme to } \\
\text { develop Industry } 4.0 \text { soft skills }\end{array}$ & 8.544 & $0.000 *$ & 0.029 & 2.218 & $0.085 \#$ & 0.008 & 24.228 & $0.000 *$ & 0.077 \\
\hline
\end{tabular}

$*, p$-value $<0.05 ; * *, p$-value $>0.05 ; \$$, Partial Eta Squared.

TABLE 9: The inter-related Wilks' lambda $(\lambda)$ value for the independent variables included in the multivariate analysis to explore the effect on the development of respondents' organisational, personal and interpersonal as well as intellectual skills.

\begin{tabular}{|c|c|c|c|c|c|}
\hline \multirow[t]{2}{*}{ Description of independent variable (permutated combinations) } & \multicolumn{5}{|c|}{ Multivariate test results } \\
\hline & Value $(\lambda)$ & $\boldsymbol{F}$ & Sig. & Partial eta-squared & Variance explained $(1-\lambda)$ \\
\hline Gender $\times$ Role of university accounting programme in developing Industry 4.0 soft skills & 0.979 & 2.014 & $0.034 *$ & 0.007 & 0.021 \\
\hline $\begin{array}{l}\text { Industry } 4.0 \text { soft skills awareness created by university accounting programme x Role of } \\
\text { university accounting programme in developing Industry } 4.0 \text { soft skills }\end{array}$ & 0.940 & 6.025 & $0.000 *$ & 0.020 & 0.060 \\
\hline $\begin{array}{l}\text { Awareness of Industry } 4.0 \text { and the impact of soft skills demanded x Role of university } \\
\text { accounting programme to develop Industry } 4.0 \text { soft skills }\end{array}$ & 0.905 & 9.730 & $0.000 *$ & 0.033 & 0.095 \\
\hline Gender x Industry 4.0 soft skills awareness created by university accounting programme & 0.980 & 6.004 & $0.000 *$ & 0.020 & 0.020 \\
\hline Gender x Awareness of Industry 4.0 and its impact on soft skills demanded & 0.985 & 4.389 & $0.004 *$ & 0.015 & 0.015 \\
\hline $\begin{array}{l}\text { Industry } 4.0 \text { soft skills awareness created by university accounting programme } \\
\text { x Awareness of Industry } 4.0 \text { and its impact on soft skills demanded }\end{array}$ & 0.992 & 2.434 & $0.064 * *$ & 0.008 & 0.008 \\
\hline
\end{tabular}

$x$ Awareness of Industry 4.0 and its impact on soft skills demanded

$\mathrm{F}$, level of significance.

$*, p<0.05$.

$* *, p>0.05$

that it played no role at all. Our research further revealed that both organisational and intellectual skills were influenced by the perceived role that a university programme plays in the development of the Industry 4.0 required soft skills $(p<0.05)$. The latter included soft skills relating to leadership ability and skill, professionalism, verbal communication, teamwork, ability to influence others, ability to solve complex problems as well as the ability to think strategically and critically. The respondents' time management, listening as well as the ability to write (personal and interpersonal skills) were not influenced by the university programme developing the soft skills demanded by Industry $4.0(p>0.05)$.

The inter-relationship between the independent variables (see Table 7) and the extent to which respondents perceived the university programme to develop their soft skills (i.e. organisational, personal and interpersonal and intellectual skills) was of particular interest to the researchers. As shown in Table 9, the inter-relationship between the awareness of Industry 4.0 and its impact on soft skills as well as the role which a university accounting programme was perceived to play in developing the skills explained approximately $9.50 \%$ of the variance in the extent to which respondents perceived the programme to develop soft skills.

As evident from Table 10, the inter-relationship between gender and respondents' perceptions of the role which a university accounting programme played in developing the soft skills appeared to only impact the development of intellectual skills $(p<0.05)$. Hence, the inter-relationship between the latter independent variables did not influence the extent to which respondents perceived a university programme to develop organisational as well as personal and interpersonal skills $(p>0.05)$. Combining the awareness created by the university programme specific to soft skills and the role that such a programme is viewed to play in this regard, our study showed that the latter inter-relationship impacts the development of respondents' intellectual skills $(p<0.05)$. This combination, however, appears not to influence the extent to which respondents perceive their organisational and personal and interpersonal skills to be developed $(p>0.05)$.

Respondents' awareness of Industry 4.0 and its impact of the required soft skills as well as the role of a university accounting programme in developing them appears to impact the development of respondents' organisational, personal and interpersonal as well as intellectual skills $(p<0.05)$. Respondents' gender and the inter-relationship with the awareness of Industry 4.0 skills show (Table 10) that the latter appears not to impact the development of respondents' organisational and intellectual skills $(p>0.05)$. However, the previous combination impacts the extent to which respondents view the development of their personal and interpersonal skills $(p<0.05)$. Respondents' gender, together with their awareness of Industry 4.0 and its impact on soft skills of the future, appears not to influence the extent of development of organisational, personal and interpersonal skills $(p>0.05)$. However, this combination influences the extent to which respondents view the university programme to develop their intellectual skills $(p<0.05)$.

The awareness that a university accounting programme creates specific to the Industry 4.0 soft skills and the relationship with respondents' awareness of Industry 4.0 and its impact on the demanded soft skills, as shown in Table 10, 
TABLE 10: Multivariate analysis of variance test results - Impact of inter-relation of independent variables on organisational (Factor 1), personal and interpersonal (Factor 2) and intellectual (Factor 3) skills.

\begin{tabular}{|c|c|c|c|c|c|c|c|c|c|}
\hline \multirow[t]{2}{*}{ Description of inter-related independent variable (permutated combinations) } & \multicolumn{3}{|c|}{$\begin{array}{l}\text { Organisational skills } \\
\text { (Factor 1) }\end{array}$} & \multicolumn{3}{|c|}{$\begin{array}{l}\text { Personal and interpersonal skills } \\
\text { (Factor 2) }\end{array}$} & \multicolumn{3}{|c|}{$\begin{array}{l}\text { Intellectual skills } \\
\quad \text { (Factor 3) }\end{array}$} \\
\hline & $F$ & Sig. & R-Squared $\dagger$ & $\boldsymbol{F}$ & Sig. & R-Squared $\dagger$ & $\boldsymbol{F}$ & Sig. & R-Squared $\dagger$ \\
\hline $\begin{array}{l}\text { Gender } \times \text { Role of university accounting programme in developing Industry } 4.0 \\
\text { soft skills }\end{array}$ & 0.283 & $0.838 * *$ & 0.001 & 0.091 & $0.965 * *$ & 0.000 & 2.825 & $0.038^{*}$ & 0.010 \\
\hline $\begin{array}{l}\text { Industry } 4.0 \text { soft skills awareness created by university accounting programme } \\
x \text { Role of university accounting programme in developing Industry } 4.0 \text { soft skills }\end{array}$ & 0.625 & $0.599 * *$ & 0.002 & 1.182 & $0.315 * *$ & 0.004 & 8.802 & $0.000 *$ & 0.030 \\
\hline $\begin{array}{l}\text { Awareness of industry } 4.0 \text { and its impact of soft skills demanded } \times \text { Role of } \\
\text { university accounting programme in developing Industry } 4.0 \text { soft skills }\end{array}$ & 9.739 & $0.000 *$ & 0.033 & 15.892 & $0.000 *$ & 0.052 & 3.026 & $0.029 *$ & 0.010 \\
\hline $\begin{array}{l}\text { Gender } \mathrm{x} \text { Industry } 4.0 \text { soft skills' awareness created by university accounting } \\
\text { programme }\end{array}$ & 0.898 & $0.344 * *$ & 0.001 & 11.417 & $0.001 *$ & 0.013 & 2.147 & $0.143 * *$ & 0.002 \\
\hline Gender $\times$ Awareness of industry 4.0 and its impact on soft skills demanded & 0.260 & $0.610 * *$ & 0.000 & 1.262 & $0.262 * *$ & 0.001 & 10.950 & $0.001 *$ & 0.012 \\
\hline $\begin{array}{l}\text { Industry } 4.0 \text { soft skills awareness created by university accounting programme } \\
x \text { Awareness of industry } 4.0 \text { and its impact on soft skills demanded }\end{array}$ & 0.001 & $0.973 * *$ & 0.000 & 4.510 & $0.034 *$ & 0.005 & 3.839 & $0.050 * * *$ & 0.004 \\
\hline $\begin{array}{l}\mathrm{F} \text {, level of significance. } \\
*, p<0.05 . \\
* *, p>0.05 \\
* * *, p=0.05 \\
+, \text { Partial eta-squared. }\end{array}$ & & & & & & & & & \\
\hline
\end{tabular}

indicates that respondents do not believe that the development of their organisational skills was influenced $(p>0.05)$. However, the latter combinations appear to impact the extent to which respondents view the development of their personal and interpersonal skills $(p<0.05)$. Regarding the development of intellectual skills and the impact of the latter inter-relationship, our study reveals that it has an impact, but this impact might not be statically significant (meaningful) because the $p$-value is equal to 0.05 .

\section{Conclusion and areas identified for future research}

The main contribution of this study was to elicit the perceptions of entry-level CAs(SA) on the soft skills acquired through the accounting programme, specifically within the context of Industry 4.0. Empirical evidence was provided, indicating that the accounting programme, to some extent, develops Industry 4.0 soft skills. The question remains, however, as to the level of proficiency (extent) to which these skills should be developed. Accordingly, this research used the SAICA levels of proficiency as a benchmark to gauge the extent to which South African accounting programme providers were perceived to develop the soft skills demanded by Industry 4.0 .

The study found that the accounting programme was perceived to have developed entry-level CA(SA)'s soft skills relating to their ability to solve complex problems, think critically, manage people effectively, coordinate others, apply judgement and decision-making, display a service orientation, negotiate effectively and display cognitive flexibility. However, the development of their creativity and emotional intelligence was lacking. This conclusion is based on the perception that these skills are not addressed in the current version of South African accountancy curriculum and professional accountancy body competency frameworks. Specific to the soft skills contained in the SAICA's competency framework, a skills mix is presented in Appendix 1, showing the combination of skills demanded by Industry 4.0. As such, these were included in the analysis and discussion of this study. In addition, the study established that entry-level CAs(SA) were aware of soft skills development. However, they did not consider that the accounting programme played a crucial role in imparting these skills. Instead, they regarded a period of practical experience to place more emphasis on well-developed soft skills as well as making them aware of the importance of such skills.

From the aforementioned, within the context of Industry 4.0 , room for improvement is clearly evident. In particular, there is a need to (1) improve the extent to which the Industry 4.0 soft skills are developed and (2) further develop professional competency in soft skills relating to creativity and emotional intelligence. It is recommended that further research should be conducted on (1) the level of proficiency which entry-level CAs(SA) are expected to master in the soft skills required by Industry 4.0, (2) the extent to which the accounting programme providers should develop these skills, (3) the methods which could be used by the accounting programme providers to impart these skills, specifically those related to creativity and emotional intelligence, and (4) the impact which the soft skills required by Industry 4.0 may have on the education of entry-level CAs(SA).

\section{Acknowledgements}

The authors would like to acknowledgment all prospective Professional accountants that complete the questionnaire as well as the SAICA for the support and sending out the questionnaire on behalf of the reseachers.

\section{Competing interests}

No potential conflict of interest was reported by the authors.

\section{Authors' contributions}

All authors contributed equally to the writing of this article.

\section{Funding information}

The research included in this study was not funded under any grant; however, the assistance of the South African 
Institute of Chartered Accountants in distributing the research questionnaire is greatly acknowledged.

\section{Data availability statement}

The response data set used in the discussion of this article is available from the corresponding author upon request.

\section{Disclaimer}

The views and arguments articulated in this study are those of the authors and not that of the journal nor that of the University of Johannesburg.

\section{References}

Agyemang, G. \& Unerman, J., 1998, 'Personal skills development and first year undergraduate accounting education: A teaching note', Accounting Education: An undergraduate accounting education: A teaching note', Accounting Education: An
International Journal 7(1), 87-92. https://doi.org/10.1080/096392898331333

Alison, L., Van den Heuvel, C., Waring, S., Power, N., Long, A. \& O'Hara, T., 2013, 'Immersive simulated learning environments for researching critical incidents: A knowledge synthesis of the literature and experiences of studying high-risk strategic decision-making', Journal of Cognitive Engineering and Decision Making 7(3), 255-272. https://doi.org/10.1177/1555343412468113

American Institute of Certified Public Accountants (AICPA), 2010, Core competency framework for entry into the accounting profession, AICPA, New York.

Anon, 2009, Questionnaire design, viewed 15 March 2019, from http://www.statcan. gc.ca/pub/12-539x/2009001/design-conception-eng.htm.

Apostolou, B., Dorminey, J.W., Hassell, J.M. \& Watson, S.F., 2013, 'Accounting education literature review (2010-2012)', Journal of Accounting Education 31(2), 107-161. https://doi.org/10.1016/j.jaccedu.2013.03.001

Arquero Montano, J.L., Donoso Anes, J.A., Hassall, T. \& Joyce, J., 2001, 'Vocational skills in the accounting professional profile: The Chartered Institute of Management Accountants (CIMA) employers' opinion', Accounting Education 10(3), 299-313.

Ashbaugh, H. \& Johnstone, K.M., 2000, 'Developing students' technical knowledge and professional skills: A sequence of short cases in intermediate financial accounting', Issues in Accounting Education 15(1), 67-88. https://doi.org/10.2308/ iace.2000.15.1.67

Australian Government, 2013, Bridging document - Core skills for work, viewed 20 April 2019, from https://docs.education.gov.au/documents/bridgingdocument-core-skills-work

Baldwin, A., Brown, C. \& Trinkle, B., 2006, 'Opportunities for artificial intelligence development in the accounting domain: The case for auditing', Intelligent Systems in Accounting, Finance and Management 14(3), 77-86.

Ballantine, J. \& McCourt Larres, P., 2009, 'Accounting undergraduates' perceptions of cooperative learning as a model for enhancing interpersonal and communication skills to interface successfully with professional accountancy education and skills to interface successfully with professional accountancy education and
training, Accounting Education: An International Journal 16(4), 387-402. https:// training', Accounting Education: An Intern

Barac, K. \& Du Plessis, L., 2014, 'Teaching pervasive skills to South African accounting students', Southern African Business Review 18, 53-79. https://doi. students, Southern African
org/10.25159/1998-8125/5645

Barac, K., 2009, 'South African training officers' perceptions of the knowledge and skills requirements of entry-level trainee accountants', Meditari Accountancy Research 17(2), 19-46. https://doi.org/10.1108/10222529200900010

Bayerlein, L. \& Timpson, M., 2017, 'Do accredited undergraduate accounting programmes in Australia meet the needs and expectations of the accounting profession?', Education and Training 59(3), 305-322.

Birkett, W.P., 1993, Competency-based standards for professional accountants in Australia and New Zealand, Australian Society of Certified Practicing Accountants, Melbourne.

Bonk, C.J. \& Smith, G.S., 1998, 'Alternative instructional strategies for creative and critical thinking in the accounting curriculum', Journal of Accounting Education 16(2), 261-293. https://doi.org/10.1016/s0748-5751(98)00012-8

Boyce, G., Williams, S., Kelly, A. \& Yee, H., 2001, Fostering deep and elaborate learning and generic (soft) skill development: The strategic use of case studies in accounting education', Accounting Education 10(1), 37-60. https://doi. org/10.1080/09639280121889

Brewer, F.C., 2001, 'Corporate audit committee effectiveness', Unpublished research report submitted in partial fulfilment of the requirements for the degree Masters of Commerce, University of the Witwatersrand, Johannesburg.

Brown, R.B. \& McCartney, S., 1995, 'Competence is not enough: Meta-competence and accounting education', Accounting Education 4(1), 43-53. https://doi. org/10.1080/09639289500000006

Bui, B. \& Porter, B., 2010, 'The expectation-performance gap in accounting education: An exploratory study', Accounting Education: An International Journal 19(1), 23-50. https://doi.org/10.1080/09639280902875556
Burrows, T., 2017, 'Bridging scarce skills gap', Mail \& Guardian, pp. 15-20, viewed 20 April 2019, from https://www.pressreader.com/south-africa/mail-guardian/20170203/ 2819, from https:/

Butler, C., 2016, 'The probability evaluation game: An instrument to highlight the skill of reflexive listening', Accounting Education 25(2), 107-123. https://doi. org/10.1080/09639284.2015.1089178

Chen, T.T.Y., 2013, 'A comparative study of what accounting employers in the United States and Hong Kong expect: Implications for curriculum and pedagogical design' Global Perspectives on Accounting Education 10, 123-134.

Coetzee, M., 2004, 'The fairness of affirmative action: An organisational justice perspective', Doctoral thesis, University of Pretoria, Pretoria.

Courtis, J.K. \& Zaid, O.A., 2002, 'Early employment problems of Australian accounting graduates: An exploratory study', Accounting Forum 26(3), 320-339. https://doi. org/10.1111/1467-6303.00092

Craig, D., 2015, How technology is disrupting the markets, World Economic Forum, viewed 14 August 2019, from https://www.weforum.org/agenda/2015/01/howtechnology-is-disrupting-the-markets/

Creswell, J.W., 2013, Research design: Qualitative, quantitative, and mixed methods approaches, 4th edn., Sage, London.

Creswell, J.W., Ebersöhn L., Eloff, I., Ferreira, R., Ivankova, N.V., Jansen, J.D. et al., 2007 First steps in research, Van Schaik Publishers, Pretoria.

Crichton, J.H, Playfoot, C.J \& Adams, I.R. (2014). 'The role of chromatin modifications in progression through mouse meiotic prophase', Journal of genetics and genomics, vol. 41, no. 3, pp. 97-106. https://doi.org/10.1016/j.jgg.2014.01.003

Dale-Jones, G., Hancock, P. \& Wiley, K., 2013, 'Accounting students in an Australian university improve their writing: But how did it happen?', Accounting Education 22(6), 544-562. https://doi.org/10.1080/09639284.2013.847321

Davis, N., 2016, What is the Fourth Industrial Revolution?, World Economic Forum, viewed 14 August 2019, from https://www.weforum.org/agenda/2016/01/whatis-the-fourth-industrial-revolution/

Delaney, Y., Pattinson, B., McCarthy, J. \& Beecham, S., 2017, 'Transitioning from traditional to problem-based learning in management education: The case of a frontline manager skills development programme', Innovations in Education and Teaching International 54(3), 214-222. https://doi.org/10.1080/14703297.2015. 1077156

Dewey, J., 1933, How we think, Henry Regnery, Chicago, IL.

Everitt, B., Landau, S., Leese, M. \& Stahl, D., 1991, Cluster analysis, 5th edn., Wiley. King's College, London, UK.

Field, A., 2013, Discovering statistics using IBM SPSS statistics, 4th edn., Sage, London, UK.

Goldman, E.F., Schlumpf, K.S. \& Scott, A.R., 2017, 'Combining practice and theory to assess strategic thinking', Journal of Strategy and Management 1(10), 488-504. assess strategic thinking', Journal of Strategy
https://doi.org/10.1108/JSMA-02-2017-0012

Gray, A., 2016, The 10 skills you need to thrive in the Fourth Industrial Revolution, World Economic Forum, viewed 9 July 2019, from https://www.weforum.org/ agenda/2016/01/the-10-skills-you-need-to-thrive-in-the-fourth-industrialrevolution/

Greenberg, P.S., 1997, 'Using a systems framework to develop higher level thinking skills in cost/management accounting: Experimental evidence', Journal of Accounting Education 15(4), 559-575.

Hadden, L.B., 2002, 'An investigation of the audit committee and its role in monitoring information technology risks. Dissertation submitted to $\mathrm{H}$. Wayne Huizenga School of Business and Entrepreneurship', Nova Southeastern University in partial fulfilment of the requirements for the degree of Doctor of Business Administration, UMI Dissertation Services.

Hair, A., Anderson, R., Black, B., \& Babin, B., 2010, Multivariate data analysis, 2nd edn., Pearson Education, Harlow, Essex, UK.

Hassall, T., Joyce, J., Montanto, J. \& Anes, J., 2005, 'Priorities for the development of vocational skills in management accountants: A European perspective', Accounting Forum 29(4), 379-394. https://doi.org/10.1016/j.accfor.2005.03.002

Henderson, M.S., 2001, 'The education of accountants - Comment', Accounting Forum 25(4), 398-401.

Howieson, B., 2003, 'Accounting practice in the new millennium: Is accounting education ready to meet the challenge?', The British Accounting Review 35(2), 69-103. https://doi.org/10.1016/s0890-8389(03)00004-0

Howieson, B., 2014, 'Who should teach what? Australian perceptions of the roles of universities and practice in the education of professional accountants', Journal of Accounting Education 32(3), 259-275. https://doi.org/10.1016/j. jaccedu.2014.05.001

Hulsart, R.W., 2002, 'The MBA degree: Does it do the job?', Doctoral thesis, University of Nebraska, Lincoln.

Hutchinson, P. \& Fleischman, G., 2003, 'Professional certification opportunities for accountants', The CPA Journal 73(3), 48-50.

Institute of Chartered Accountants in Australia (ICAA), 1998, The future for business, ICAA, Melbourne.

International Accounting Education Standards Board (IAESB), 2014, Initial professiona development - Professional skills (Revised) (IES3), IFAC, New York, viewed 14 July 2019, from https://www.ifac.org/publications-resources/ies-3-initial-professionaldevelopment-professional-skills-revised

International Federation of Accountants (IFAC), 2015, IES 3, Initial professional development-Professional skills (Revised), viewed 14 July 2019, from https:// www.ifac.org/publications-resources/ies-3-initial-professional-developmentprofessional-skills-revised 
International Federation of Accountants (IFAC), 2017, Handbook of internationa education pronouncements, viewed 20 August 2019, from https://www.ifac.org/ system/files/publications/files/2017-Handbook-of-International-Educationsystem/files/public
Pronouncements.PDF

Jackling, B. \& De Lange, P., 2009, 'Do accounting graduates' skills meet the expectations of employers? A matter of convergence or divergence', Accounting Education: An InternationalJournal18(4/5),39-385.https://doi.org/10.1080/09639280902719341

Jackson, R.B. \& Cherrington, J.O., 2002, 'IT instruction methodology and minimum competency for accounting students', Information Executive 6(3), 13.

Johnstone, K.M. \& Biggs, S.F., 1998, 'Problem-based learning: Introduction, analysis and accounting curricula implications', Journal of Accounting Education 16(3/4), 407-427. https://doi.org/10.1016/s0748-5751(98)00026-8

Kennan, M.A., Cecez-Kecmanovic, D., Willard, P. \& Wilson, C.S., 2009, 'IS knowledge and skills sought by employees: A content analysis of Australian IS early caree online job advertisements', Australasian Journal of Information Systems 15(2), 169-190. https://doi.org/10.3127/ajis.v15i2.455

Kern, B.B., 2002, Enhancing accounting students' problem-solving skills: The use of a hands-on conceptual model in an active learning environment', Accounting Education: An International Journal 11(3), 235-256. https://doi.org/ 10.1080/09639280210141680

Kim, T.S., Ghosh, B.C. \& Meng, L.A., 1993, 'Selection criteria: Perception gap between employers and accounting graduates', Singapore Accountant 9(4), 32-33.

Kleinbaum, D. \& Klein, M., 2012, Survival analysis: A self-learning text (Statistics for biology and health), 3rd edn., Springer Science and Business Media, Berlin.

LaFrancois, H.A., 1992, 'The marketing of an accounting graduate: Characteristics most desired by CPA firms', Journal of Education for Business 67(4), 206-209. https://doi.org/10.1080/08832323.1992.10117544

Marx, B., 2008, 'An analysis of the development, status and functioning of audit committees at large listed companies in South Africa', Doctoral thesis, University of Johannesburg, Johannesburg.

Mathews, R., Jackson, M. \& Brown, P., 1990, Accounting in higher education: Report of the review of the accounting discipline in higher education: Volume 1, Australian Government, Canberra.

Meads, D., 2017, Here's how Africa can take advantage of the Fourth Industrial Revolution, World Economic Forum, viewed 20 May 2019, from https://www.
weforum.org/agenda/2017/05/heres-how-africa-can-take-advantage-of-theweforum.org/agenda/2017/

Miles, M., Huberman, M. \& Saldana, J., 2014, Qualitative data analysis: A methods sourcebook. Qualitative data analysis: A methods sourcebook, 3rd edn., Sage, London.

Milliron, V.C., 2012, 'CPAs explore a pre-certification pathway to excellence', The Accounting Educators' Journal 27(1), 281-298.

Mohamed, E.K. \& Lashine, S.H., 2003, 'Accounting knowledge and skills and the challenges of a global business environment', Managerial Finance 29(7), 3-16. https://doi.org/10.1108/03074350310768319

Moon, J., 2008, Critical thinking: An exploration of theory and practice, Routledge London.

Mouton, J., 2001, How to succeed in your master's and doctoral studies. A South African guide and resource book, Van Schaik Publishers, Pretoria.

National Centre for Vocational Education Research (NCVER), 2003, viewed 14 August 2019, from http://www.ncver.edu.au/ research/proj/nr2102b.pdf

O'Connell, B., Carnegie, G.D., Carter, A.J., Hancock, P., Helliar, C.V. \& Watty, K., 2015 Shaping the future of accounting in business education in Australia, CPA Australia, Melbourne.

Oliver, B., Whelan, B., Hunt, L. \& Hammer, S., 2011, 'Accounting graduates and the capabilities that count: Perceptions of graduates, employers and accounting academics in four Australian universities', Journal of Teaching and Learning for GraduateEmployability2(1),s.p.https://doi.org/10.21153/jtlge2011vol2no1art550

Olivier, M., 2017, Building the new, viewed 15 August 2019, from https://www.saica. co.za/ThoughtLeadership/nitiatives/CA2025/tabid/4097/itemid/5865/language/ n-ZA/language/en-ZA/Default.aspx.

Paisey, C. \& Paisey, N.J., 2004, 'An analysis of accounting education research in accounting education: An international journal - 1992-2001', Accounting Education 13(1), 69-99. https://doi.org/10.1080/0963928042000207396

Picard, C.F., Durocher, S. \& Gendron, Y., 2014, 'From meticulous professionals to superheroes of the business world: A historical portrait of a cultural change in the field of accountancy', Accounting, Auditing \& Accountability Journal 27(1), 73-118. https://doi.org/10.1108/aaaj-09-2012-1087

Rebele, J.E., 1985, 'An examination of accounting students' perceptions of the importance of communication skills in public accounting', Issues in Accounting Education 3, 41-50.

Rudman, R. \& Sexton, N., 2017, The leader within drives the leader without Accountancy SA (ASA), SAICA, viewed 1 February 2017, from https://www. accountancysa.org.za/focus-this-month-leadership

Schwab, K., 2016, The Fourth Industrial Revolution: What it means, how to respond World Economic Forum, viewed 10 August 2019, from https://www.weforum.org/ agenda/2016/01/the-fourth-industrial-revolution-what-it-means-and-how-torespond/

Sergenian, G.K. \& Pant, L.W., 1998, 'Increasing students' professionalism: A careers project for accounting majors', Issues in Accounting Education 13(2), 429-442.
Siriwardane, H.P., Low, K.Y. \& Blietz, D., 2015, 'Making entry-level accountants better communicators: A Singapore-based study of communication tasks, skills and communicators: A Singapore-based study of communication tasks, skills and attributes', Journal of Accounting
org/10.1016/j.jaccedu.2015.08.001

South African Institute of Chartered Accountants (SAICA), 2014, Competency framework. Competencies of a CA (SA) at the point of the Initial Test of Competence (ITC) (assessment of core technical knowledge), viewed 10 January 2019, from https://www.saica.co.za/Portals/0/LearnersStudents/documents/Detailed Guidance_tothe_competency_framework_for_the_academic_programme Updated_and_approved July_2014.pdf

South African National Qualifications Authority (SANQA), 2012, Level description for the South African National qualifications framework, Department of Higher the South African Nation
Education and Training.

Steenkamp, G., 2012, 'Student perceptions regarding the new training programme for chartered accountants', Journal of Economic and Financial Sciences 5(2), 485-502. https://doi.org/10.4102/jef.v5i2.295

Strauss, K., 2016, These are the skills bosses say new college grads do not have, viewed 10 April 2019, from https://www.forbes.com/sites/karstenstrauss/ 2016/05/17/these-are-the-skills-bosses-say-new-college-grads-do-nothave/\#12979d835491.

Tan, L.M. \& Laswad, F., 2018, 'Professional skills required of accountants: What do job advertisements tell us?', Accounting Education 27(4), 403-432. https://doi.org/10 $.1080 / 09639284.2018 .1490189$

Tempone, I. \& Martin, E., 2003, 'Iteration between theory and practice as a pathway to developing generic skills in accounting', Accounting Education: An International Journal 12(3), 227-244. https://doi.org/10.1080/0963928032000128485

The Telegraph (TT), 2014, Soft skills valued over technical knowledge in graduates, viewed 05 April 2019, from http://www.telegraph.co.uk/education/ universityeducation/10999619/Soft-skills-valued-over-technical-knowledge-ingraduates.html

Thomas, T.A., 2000, 'A teaching environment for learning soft skills applicable to information systems development', Doctoral thesis, University of Pretoria, Pretoria.

Tinker, T. \& Feknous, B., 2001, 'Developing the socio-political skills of accounting students: A mixed synchronous and asynchronous learning strategy', Pacific Accounting Review 13(1), 1932. https://doi.org/10.1108/eb037955

University World News (UWN), 2016, Employers lament lack of soft skills in graduates, viewed 10 July 2019, from http://www.universityworldnews.com/ article.php?story=20160119123408402.

Usoff, C. \& Feldmann, D., 1998, 'Accounting students' perceptions of important skills for career success', Journal of Education for Business 73(4), 215-220. https://doi. for career success', Journal of Educatic
org/10.1080/08832329809601633

Van Oordt, T. \& Sullivan, I., 2017, Experiential learning as a method to address the employer expectation gap on pervasive competencies in an undergraduate taxation curriculum, Proceedings of the Southern African Accounting Association Biennial International Conference, viewed 10 May 2019, from http://www.saaa. org.za/Downloads/Publications/EDU016\%20Experiential\%20learning\%20as\%20 arg.za/Downloads/Publications/EDU016\%20 Experiential\%20learning\%20as\%20 a $\% 20$ method $\% 20$ to $\% 20$ address $\% 20$ the $\% 20$ exployer $\% 2$ expectation $\% 20$ gap $\% 20$ on $\% 20$ pervasive $\% 20$ com
taxation\%20curriculum.pdf

Viviers, H.A., 2016, 'Taking stock of South African accounting students' pervasive qualities and skills development: Are we making progress?', South African Journal qualities and skills development: Are we making progress?', South Africa
of Higher Education 30(2), 242-263. https://doi.org/10.20853/30-2-645

Watty, K., Jackling, B. \& Wilson, R.M.S., 2012, Personal transferable skills in accounting education, Routledge, London.

Weiss, R., 2005, 'Audit committee characteristics and monitoring effectiveness', Dissertation submitted to the Graduate Faculty of Business in partial fulfilment of the requirements for the degree of Doctor of Philosophy, UMI Dissertation Services, University of New York, New York.

Wells, P., Gerbic, P., Kranenburg, I. \& Bygrave, J., 2009, 'Professional skills and capabilities of accounting graduates: The New Zealand expectation gap?', Accounting Education 18(4/5), 403-420. https://doi.org/10.1080/09639280902719390

Whiley, D., Witt, B., Colvin, R.M., Arrue, R.S. \& Kotir, J., 2017, 'Enhancing critical thinking skills in first-year environmental management students: A tale of curriculum design, application and reflection', Journal of Geography in Higher Education 41(2), 166-181. https://doi.org/10.1080/03098265.2017.1290590

Willcoxson, L., Wynder, M. \& Laing, G.K., 2010, 'A whole-of-program approach to the development of generic and professional skills in a university accounting program Accounting Education 19(1), 65-91. https://doi.org/10.1080/09639280902886082

World Economic Forum (WEF), 2016, The future of jobs employment, skills and workforce strategy for the Fourth Industrial Revolution. Executive Summary, viewed 05 February 2019, from http://www3.weforum.org/docs/WEF_FOJ Executive_Summary_Jobs.pdf

Wunsche, A., 2016, Technological disruption of capital markets and reporting? An introduction to blockchain', Chartered Professional Accountants Canada (CPA) viewed 10 January 2019, from https://webcache.googleusercontent.com/search? q=cache:LzaVpl8PXqAJ:https://www.cpacanada.ca/-/media/site/business-andaccounting-resources/docs/g10157-rg-technological-disruption-of-capitalmarkets-reporting-introduction-to-blockchain-october-2016. pdf $+\& c d=1 \& h|=e n \& c t=c| n k \& g l=z a$

Yong, A.G, \& Pearce, S., 2013, 'A beginner's guide to factor analysis: Focusing on exploratory factor analysis', Tutorials in Quantitative Methods for Psychology 9(2), 79-94. https://doi.org/10.20982/tqmp.09.2.p079

Appendix 1 starts on the next page $\rightarrow$ 


\section{Appendix 1}

TABLE 1-A1: South African Institute of Chartered Accountants' current soft skills requirements in relation to the World Economic Forum's prediction for 2020.

\begin{tabular}{|c|c|}
\hline $\begin{array}{l}\text { World Economic Forum soft skills for } 2020 \\
\text { (World Economic Forum 2016) }\end{array}$ & SAICA's current soft skill requirements (SAICA 2014) in relation to those predicted by the World Economic Forum \\
\hline Complex problem-solving & - Problem-solving (Alison et al. 2013; Apostolou et al. 2013; Australian Government 2013; IFAC 2017; SAICA 2014) \\
\hline Critical thinking & - Critical thinking (Australian Government 2013; Dewey 1933; IFAC 2017; Moon 2008; SAICA 2014; Whiley et al. 2017) \\
\hline Creativity & - None \\
\hline People management & $\begin{array}{l}\text { - Leadership (Bayerlein \& Timpson 2017; IFAC 2017; SAICA 2014) } \\
\text { - Influencing others (Australian Government 2013; Delaney et al. 2017; IFAC 2017; SAICA 2014) } \\
\text { - Professionalism (IFAC 2017; SAICA 2014) } \\
\text { - Team work (IFAC 2017; Oliver et al. 2011; SAICA 2014) } \\
\text { - Verbal communication (IFAC 2017; SAICA 2014) } \\
\text { - Time management (IFAC 2017; SAICA 2014) } \\
\text { - Ethical awareness (IFAC 2017; SAICA 2014; Willcoxson, Wynder \& Laing 2010) }\end{array}$ \\
\hline Coordinating others & $\begin{array}{l}\text { - Influencing others (Australian Government 2013; Delaney et al. 2017; IFAC 2017; SAICA 2014) } \\
\text { - Professionalism (IFAC 2017; SAICA 2014) } \\
\text { - Team work (IFAC 2017; Oliver et al. 2011; SAICA 2014) } \\
\text { - Verbal communication (IFAC 2017; Montano et al. 2001; SAICA 2014) }\end{array}$ \\
\hline Emotional intelligence & - None \\
\hline Judgement and decision-making & $\begin{array}{l}\text { - Problem-solving (Australian Government 2013; IFAC 2017; SAICA 2014) } \\
\text { - Critical thinking (Australian Government 2013; Dewey 1933; IFAC 2017; Moon 2008; Whiley et al. 2017; SAICA 2014) } \\
\text { - Leadership (Bayerlein \& Timpson 2017; IFAC 2017; SAICA 2014) } \\
\text { - Influencing others (Australian Government 2013; Delaney et al. 2017; IFAC 2017; SAICA 2014) } \\
\text { - Professionalism (IFAC 2017; SAICA 2014) } \\
\text { - Team work (IFAC 2017; Oliver et al. 2011; SAICA 2014) } \\
\text { - Verbal communication (IFAC 2017; Montano et al. 2001; SAICA 2014) } \\
\text { - Strategic thinking (IFAC 2017; Goldman, Schlumpf \& Scott 2017; SAICA 2014) } \\
\text { - Listening (Butler 2016; IFAC 2017; Montano et al. 2001; SAICA 2014) } \\
\text { - Writing (Dale-Jones, Hancock \& Wiley 2013; Montano et al. 2001) } \\
\text { - Ethe management (IFAC 2017; SAICA 2014; Watty et al. 2012) } \\
\text { - Ethical awareness (IFAC 2017; SAICA 2014; Willcoxson et al. 2010) }\end{array}$ \\
\hline Service orientation & $\begin{array}{l}\text { - Problem-solving (Apostolou et al. 2013; Australian Government 2013; IFAC 2017; SAICA 2014) } \\
\text { - Critical thinking (Australian Government 2013; Dewey 1933; Moon 2008; IFAC 2017; Whiley et al. 2017; SAICA 2014) } \\
\text { - Leadership (IFAC 2017; Bayerlein \& Timpson 2017; SAICA 2014) } \\
\text { - Influencing others (Australian Government 2013; Delaney et al. 2017; IFAC 2017; SAICA 2014) } \\
\text { - Professionalism (IFAC 2017; SAICA 2014) } \\
\text { - Team work (IFAC 2017; Oliver, Whelan, Hunt \& Hammer 2011; SAICA 2014) } \\
\text { - Verbal communication (IFAC 2017; Montano et al. 2001; SAICA 2014) } \\
\text { - Strategic thinking (IFAC 2017; Goldman et al. 2017; SAICA 2014) } \\
\text { - Listening (Butler 2016; IFAC 2017; Montano et al. 2001; SAICA 2014) } \\
\text { - Writing (Dale-Jones et al. 2013; Montano et al. 2001) } \\
\text { - Time management (IFAC 2017; SAICA 2014; Watty et al. 2012) } \\
\text { - Ethical awareness (IFAC 2017; SAICA 2014; Willcoxson et al. 2010) }\end{array}$ \\
\hline Negotiation & $\begin{array}{l}\text { - Problem-solving (Alison et al. 2013; Apostolou et al. 2013; Australian Government 2013; IFAC 2017; SAICA 2014) } \\
\text { - Critical thinking (Australian Government 2013; Dewey 1933; Moon 2008; IFAC 2017; SAICA 2014; Whiley et al. 2017) } \\
\text { - Leadership (IFAC 2017; Bayerlein \& Timpson 2017; SAICA 2014) } \\
\text { - Influencing others (Australian Government 2013; Delaney et al. 2017; IFAC 2017; SAICA 2014) } \\
\text { - Professionalism (IFAC 2017; SAICA 2014) } \\
\text { - Team work (IFAC 2017; Oliver et al. 2011; SAICA 2014) } \\
\text { - Verbal communication (IFAC 2017; Montano et al. 2001; SAICA 2014) } \\
\text { - Strategic thinking (IFAC 2017; Goldman et al. 2017; SAICA 2014) } \\
\text { - Listening (Butler 2016; IFAC 2017; Montano et al. 2001; SAICA 2014) } \\
\text { - Writing (Dale-Jones et al. 2013; Montano et al. 2001) }\end{array}$ \\
\hline Cognitive flexibility & $\begin{array}{l}\text { - Problem-solving (Alison et al. 2013; Apostolou et al. 2013; Australian Government 2013; IFAC 2017; SAICA 2014) } \\
\text { - Critical thinking (Australian Government 2013; Dewey 1933; Moon 2008; IFAC 2017; Whiley et al. 2017; SAICA 2014) } \\
\text { - Leadership (IFAC 2017; Bayerlein \& Timpson 2017; SAICA 2014) } \\
\text { - Influencing others (Australian Government 2013; Delaney et al. 2017; IFAC 2017; SAICA 2014) } \\
\text { - Professionalism (IFAC 2017; SAICA 2014) } \\
\text { - Team work (IFAC 2017; Oliver et al. 2011; SAICA 2014) } \\
\text { - Verbal communication (IFAC 2017; Montano et al. 2001; SAICA 2014) } \\
\text { - Strategic thinking (IFAC 2017; Goldman et al. 2017; SAICA 2014) } \\
\text { - Listening (Butler 2016; IFAC 2017; Montano et al. 2001; SAICA 2014) } \\
\text { - Ethical awareness (IFAC 2017; SAICA 2014; Willcoxson et al. 2010) }\end{array}$ \\
\hline
\end{tabular}

SAICA, South African Institute of Chartered Accountants. 